\title{
Hydrogen steelmaking, part 2: competition with other net-zero steelmaking solutions - geopolitical issues ${ }^{2 / 2}$
}

\author{
Jean-Pierre Birat ${ }^{*}$, Fabrice Patisson, and Olivier Mirgaux
}

IF Steelman, Semécourt, France

Received: 29 July 2021 / Accepted: 6 December 2021

\begin{abstract}
Hydrogen direct reduction is one of the technological process solutions for making steel, explored in the framework of reducing GHG emissions from the steel sector (Net-Zero steel). However, there are many other solutions, which have been explored since the 1980s or earlier. The present paper starts by comparing all these different options in terms of 3 criteria: energy needs, GHG emissions and total production cost of steel. The extensive simulations carried out as part of the ULCOS Program, which are still fully valid, indeed show that, while energy is always rather close to the efficient integrated steel mill benchmark (within 15-20\%), there are a series of solutions for significantly cutting GHG emissions, some of which even leading to negative emissions. Two families of solutions can usefully be compared with each other, as they are both based on the use of electricity: hydrogen direct reduction, from green hydrogen generated from green electricity, and electrolysis of iron ore, such as the $\Sigma$ IDERWIN process, also based on zero-carbon electricity. They are quite close with regards to the 3 above criteria, with a slight advantage for electrolysis. Focusing now on hydrogen steelmaking, the process developed over the last 70 years: the H-Iron process was first explored in 1957 at laboratory level, then it was followed by an industrial first plant in the late 1980s, which did not fully deliver (CIRCORED); a subproject within ULCOS (2000s) followed, then some projects in Germany and Austria (SALCOS, SUSTEEL, MATOR, based on direct reduction and smelting reduction, 2010s) and then, very recently, occurred an explosion of projects and announcements of industrial ventures, both for generating hydrogen and for producing DRI, located in Europe, Russia and China. Broader questions are then tackled: how much hydrogen will be called upon, compared to today and future needs, regarding in particular $\mathrm{H}_{2}$-e-mobility; carbon footprint and costs; maturity of the various processes; and geopolitical issues, such as possible locations of $\mathrm{H}_{2}$-generation and $\mathrm{H}_{2}$-steel production.
\end{abstract}

Keywords: steel production / climate change / GHG emission abatement / hydrogen steelmaking / electrolysis of iron ore

Résumé. La réduction à l'hydrogène, partie 2 : concurrence avec d'autres filières de production net-zéro-questions géopolitiques. La réduction directe à l'hydrogène est l'une des filières de production d'acier qui est explorée par le secteur de la sidérurgie pour réduire ses émissions de gaz à effet de serre (GES). Cependant, il existe un grand nombre d'autres filières possibles qui ont été étudiées depuis les années 1990 ou avant. Cette publication compare d'abord toutes ces solutions par rapport à 3 critères : les besoins en énergie, les émissions de GES et les coûts de production globaux de l'acier. Les simulations très détaillées conduites dans le cadre du programme ULCOS, qui n'ont pas pris une ride, montrent que le niveau d'énergie est toujours proche de celui d'une usine intégrée de référence de bon niveau (à 15-20\% près), alors qu'il existe un grand nombre de solutions pour réduire les émissions de GES, dont certaines conduisent même à des émissions négatives. Deux familles de solutions particulières méritent d'être comparées entre elles, car toutes deux utilisent l'électricité comme source d'énergie : la réduction directe à l'hydrogène vert issu d'électricité verte et l'électrolyse du minerai de fer, par le procédé $\Sigma$ IDERWIN par exemple, basée, elle aussi, sur de l'électricité verte. Ces deux familles de procédés sont très proches l'une de l'autre, avec un léger avantage à l'électrolyse. En ce qui concerne la réduction à l'hydrogène, la filière s'est développée conceptuellement au cours des 70 dernières années: au départ le procédé H-Iron en a exploré le principe en 1957, puis une première usine de production a suivi à la fin des années 1980 ,

\footnotetext{
From a presentation given to the H2 Green Steel, Web-Workshop, 7th, 21st, 28th May

* e-mail: jean-pierre.birat@ifsteelman.eu
} 
mais sans confirmation véritablement industrielle; un sous-projet du programme ULCOS a suivi (années 2000); des projets sont alors apparus en Allemagne et en Autriche (SALCOS, SUSTEEL, MATOR, basés sur la réduction directe et la réduction-fusion, années 2010) ; très récemment, une explosion de projets et d'annonces de projets industriels pour produire de l'hydrogène et/ou du DRI, en Europe surtout mais aussi en Russie et en Chine. Puis, on soulève une série de questions plus larges : de combien d'hydrogène aura-t-on besoin par rapport à la répartition actuelle de la demande et à celle qu'on attend dans l'avenir, compte-tenu, en particulier, de la e-mobilité liée à ce gaz; empreintes carbones et coûts attendus; maturité des différentes filières ; questions géopolitiques, telles que la localisation géographique des usines d'hydrogène et de réduction du fer.

Mots clés: production d'acier / changement climatique / réduction des émission de GES / réduction à l'hydrogène / électrolyse du minerai de fer

La vraie générosité envers l'avenir consiste à tout donner dans le présent. Albert Camus

\section{Introduction}

The steel sector has been investigating low-carbon solutions for producing steel, including hydrogen-based ones, for the last 60 years at least $[1,2]$. Many programs were conducted during this period of time, including several large international ones: the ULCOS Program in Europe [3,4] and the $\mathrm{CO}_{2}$ Breakthrough Program at world scale $[5,6]$ were the most important.

Recently, a host of new programs of various kinds has been launched, in phase with the Paris COP21 Agreement and the Green Deal commitment of the European Commission. The urgency related to Climate Change has become more widely understood and a concerted effort seems under way to find solutions to move forward effectively: they include political and financial solutions, reaching beyond simple technology explorations. The picture is that of an explosion of activities, even a kind of big bang.

The present article proposes an overview of the state of the art regarding steel, i.e., of the endeavors presently called "Net-Zero steel solutions", with a special attention to hydrogen.

Attention will be paid particularly to electricity-based processes - of course green electricity, which are on the one hand hydrogen-direct reduction based on hydrogen generated by electrolysis of water and direct electrolysis of iron ore.

Then a series of questions, of a broader scope will be tackled: (1) Why is this hydrogen enthusiasm happening now? (2) How much hydrogen and green electricity would this call upon compared to traditional uses of the gas $\left(\mathrm{NH}_{3}\right)$ and to the up-coming ones (e-mobility)? (3) What would be a comprehensive environmental footprint of the new $\mathrm{H}_{2}$-process route? (4) What about costs, including carbon cost, availability of green energy (green certificates?), and who will be paying for them? (5) How much development is still needed, what would be a schedule for climbing the TRL scale up to TRL 12 , what kind of scenarios are likely, including the co-development of the various zero-carbon solutions? (6) Where should $\mathrm{H}_{2}$ and DRI production be located in the world, with respect to resources and markets, how much international trade of both, how would this affect the $\mathrm{CO}_{2}$ rent?

\section{Steel production 101}

Steel production is organized today along two major routes: - one route is based on the use of iron ores (oxides), which are chemically/metallurgically reduced at high temperature either in the presence of carbon (coal or coke) in a smelting-reduction (SR) reactor or of natural gas ${ }^{1}$ in a direct reduction reactor;

- the other route is based on the reutilization of steel scrap, melted in an Electric Arc Furnace (EAF).

The iron ore route accounted for $71.9 \%$ of world production in 2019 and the EAF route for $27.7 \%$ [7]. The production of iron ore was $2228 \mathrm{Mt}$, of hot metal (pig iron) $12807 \mathrm{Mt}$, of prereduced iron 107.6 Mt and of crude steel 1867.5 Mt.

From the standpoint of physical chemistry, there is a large number of options for organizing other routes and thus for imagining low or zero-carbon ones - which might involve breakthrough solutions.

Figure 1 presents the three main physical options for making steel, two of which are out of reach within our present technical paradigm, i.e., within the limits of achievable technologies: temperature decomposition (too high temperatures) and vacuum decomposition (too much of a vacuum) [8]. One solution is within reach, based on electricity and more particularly on electrolysis, in this case direct electrolysis of iron ore.

Figure 2 focuses on chemical solutions, i.e., solutions that remove oxygen from ores but form chemical compounds that require lower temperature than the physical solutions discussed before. This means using reducing agents, the most common one, readily available, being carbon. Hydrogen is another reducing agent, although, contrary to carbon, it is not a resource available from the geosphere (coal, coke), nor from the biosphere (biomass, charcoal). Electrons are also reducing agents, made available either by electricity - and we are back to electrolysis as before-and from living organisms such as bacteria (e.g., bioleaching, etc.) [9].

There are other reducing agents, such as hydrazine $\left(\mathrm{H}_{2} \mathrm{~N}-\mathrm{NH}_{2}\right)$ or metals more electronegative than iron, such as aluminum, silicon, calcium, etc. We will not discuss

1 The reducing agents are, respectively, $\mathrm{CO}$ and syngas $\left(\mathrm{CO}+\mathrm{H}_{2}\right.$ mixture). Direct reduction by carbon is fairly rare. 


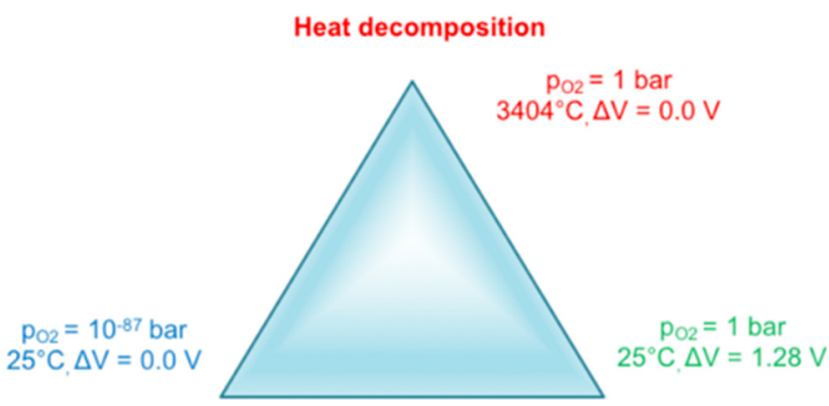

Oxygen vacuum decomposition Electrolytic decomposition

Fig. 1. Physical solutions for producing metallic iron from oxide ores.

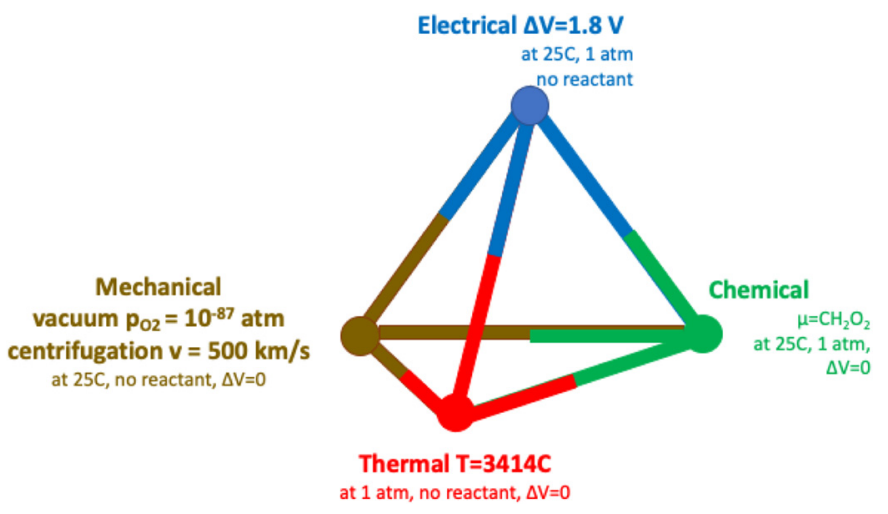

Fig. 3. Concatenation of the schemes shown in Figures 1 and 2 (courtesy of ArcelorMittal).

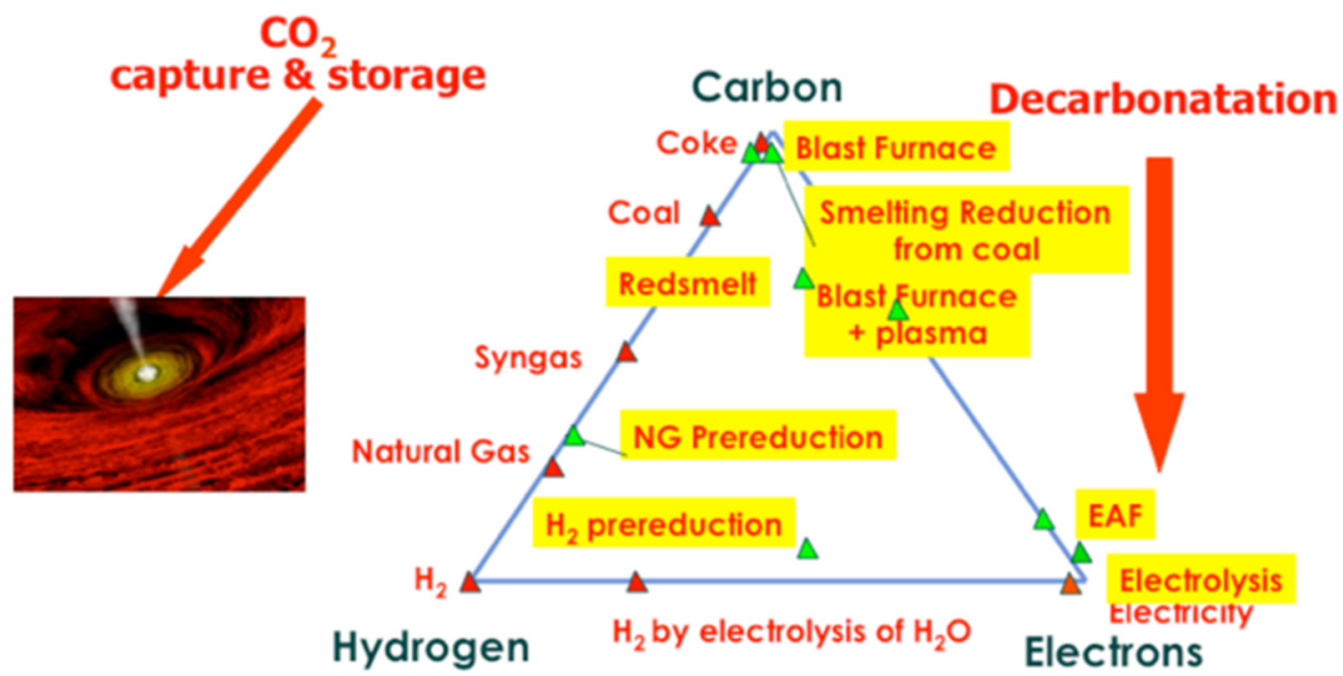

Fig. 2. Chemical/metallurgical routes for reducing iron oxides. Shown in black are the "elementary" reducing agents (carbon, hydrogen), in red the "composite" reducing agents Syngas, natural gas), in green triangles and red letters highlighted in yellow, existing or potential processes (smelting reduction, blast furnace). The red arrows show two major solution paths: decarbonization/ decarbonatation and CCS/CCU.

them in this paper, as they raise practical or economic issues and are only used at the margin [8]. Both conceptual presentations are brought together in Figure 3.

\section{Comparing various options for low-carbon steel production}

An extensive analysis of the possible options for low-carbon steel production was carried out as part of the ULCOS Program [10-13]: it involved detailed process and economic modeling of 46 routes selected among an initial list of about 80 of them.

This is the most extensive and exhaustive study of this kind published until today. It is based on a carefully crafted methodology, whereby scope I and scope II emissions are taken on board and the perimeter of the steel mill is defined in a coherent and inclusive way across the many different options (e.g., electricity generation from steelmill gases is included within the energy balance, but also cokemaking or the production of lime; the quantity of scrap added in the converter is also normalized across the routes, etc.). See the original publications for an exhaustive description of these assumptions.

The relevant comparisons are shown in Figures 4-9. The color code is black for the BF, red for the TGRBF, blue for smelting reduction, yellow for natural gas direct reduction, grey and purple for hydrogen direct reduction, rose for electrolysis and red again for BF variants with plasma injected at the tuyeres:

- Figure 4 shows the energy requirement of the various routes. They are fairly coherent, at the level of $15 \mathrm{GJ} / \mathrm{t}_{\mathrm{HRC}}$, with all the ULCOS routes performing slightly better than the benchmark/reference blast furnaces (the two black bars at the left). The best routes are 15 to $20 \%$ below the benchmark. Except for the direct reduction routes, one natural gas or all hydrogen ones, which are slightly higher. All processes are optimized in terms of energy needs, the BF of course, but also the "paper" 


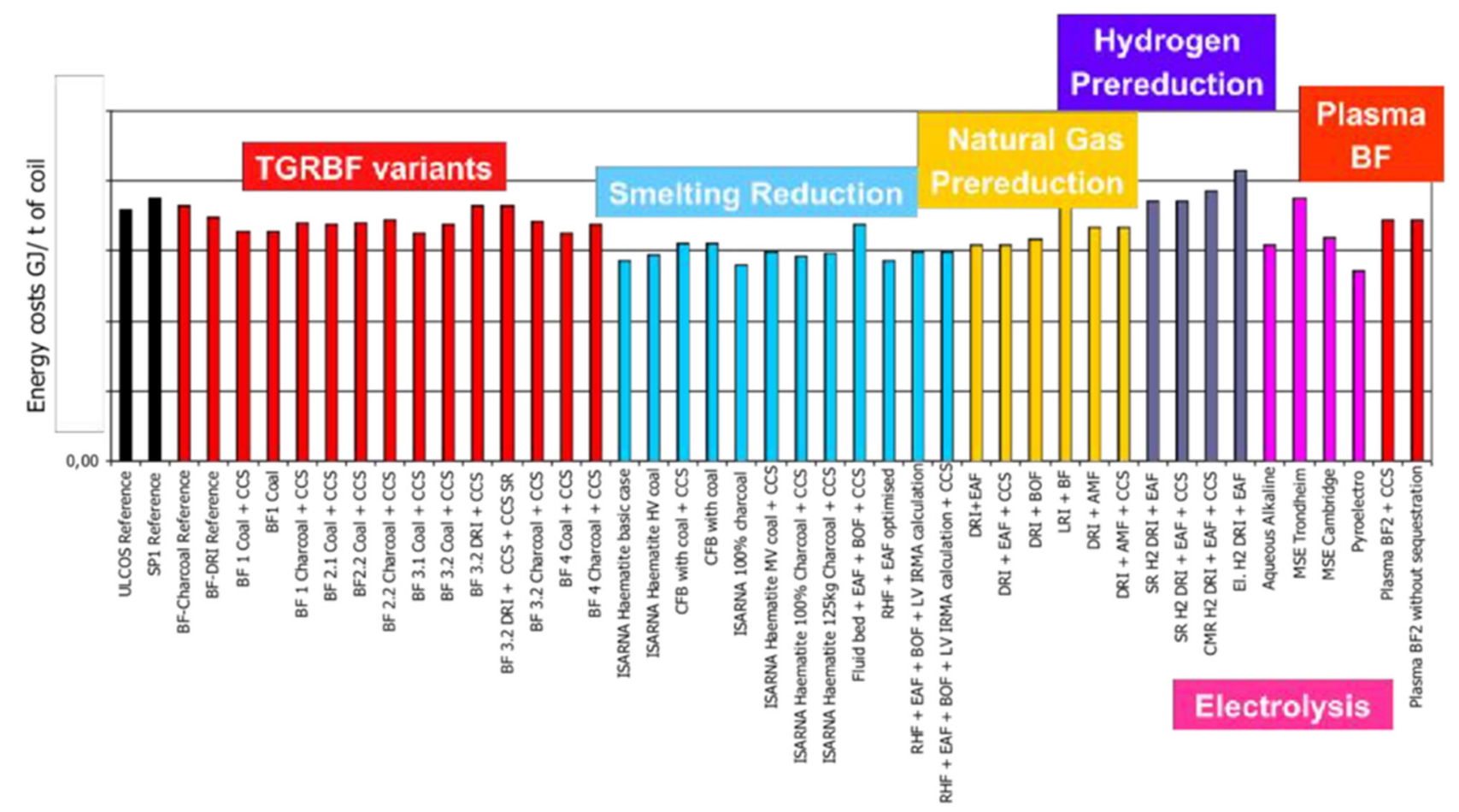

Fig. 4. Energy requirements of 46 steel producing routes examined in the ULCOS Program.

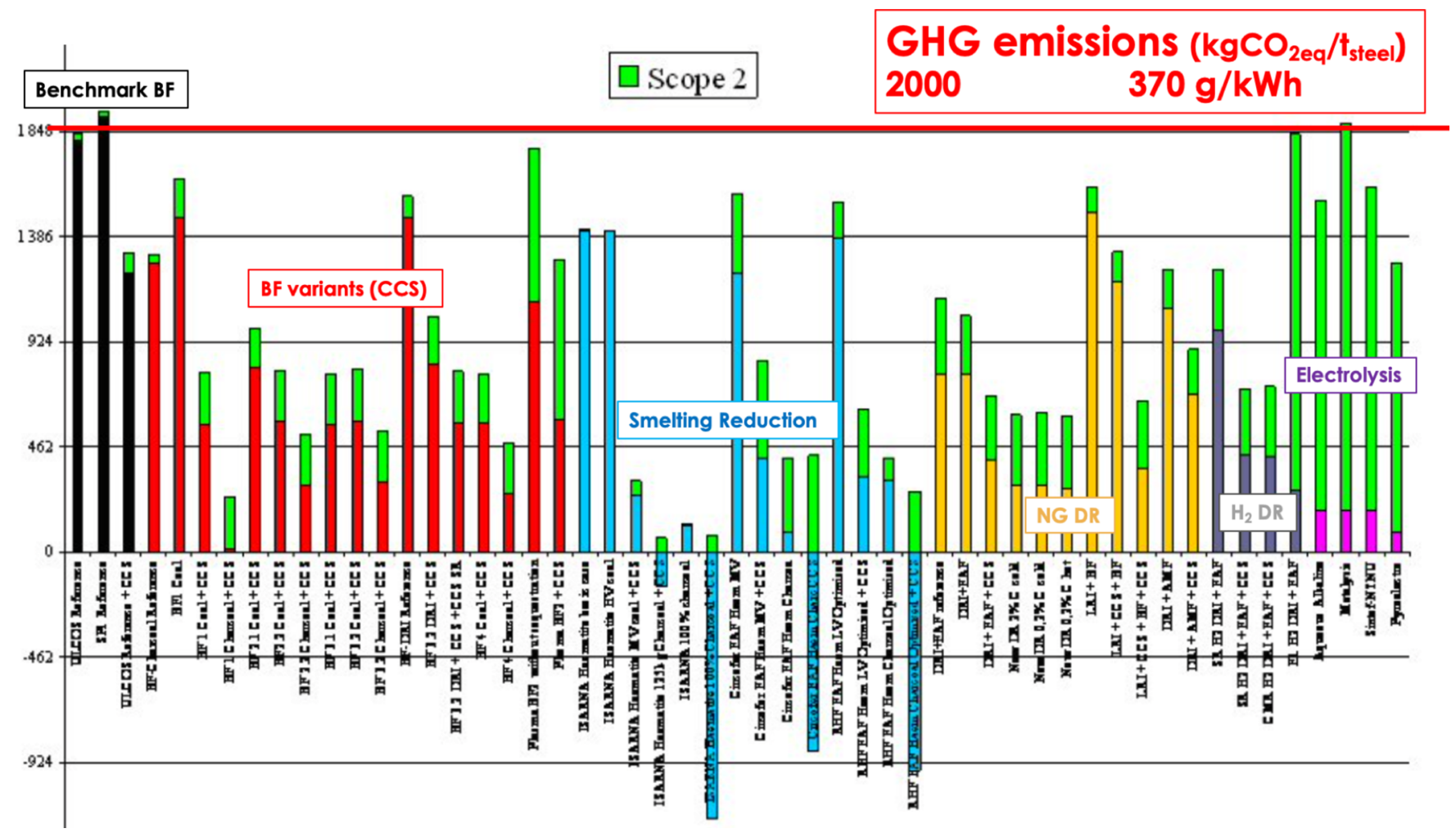

Fig. 5. $\mathrm{CO}_{2}$ emissions ( $\mathrm{kg} \mathrm{CO} / \mathrm{tHRC}$ ), $370 \mathrm{~g} \mathrm{CO}_{2} / \mathrm{kWh}$, European grid value, 2000. 


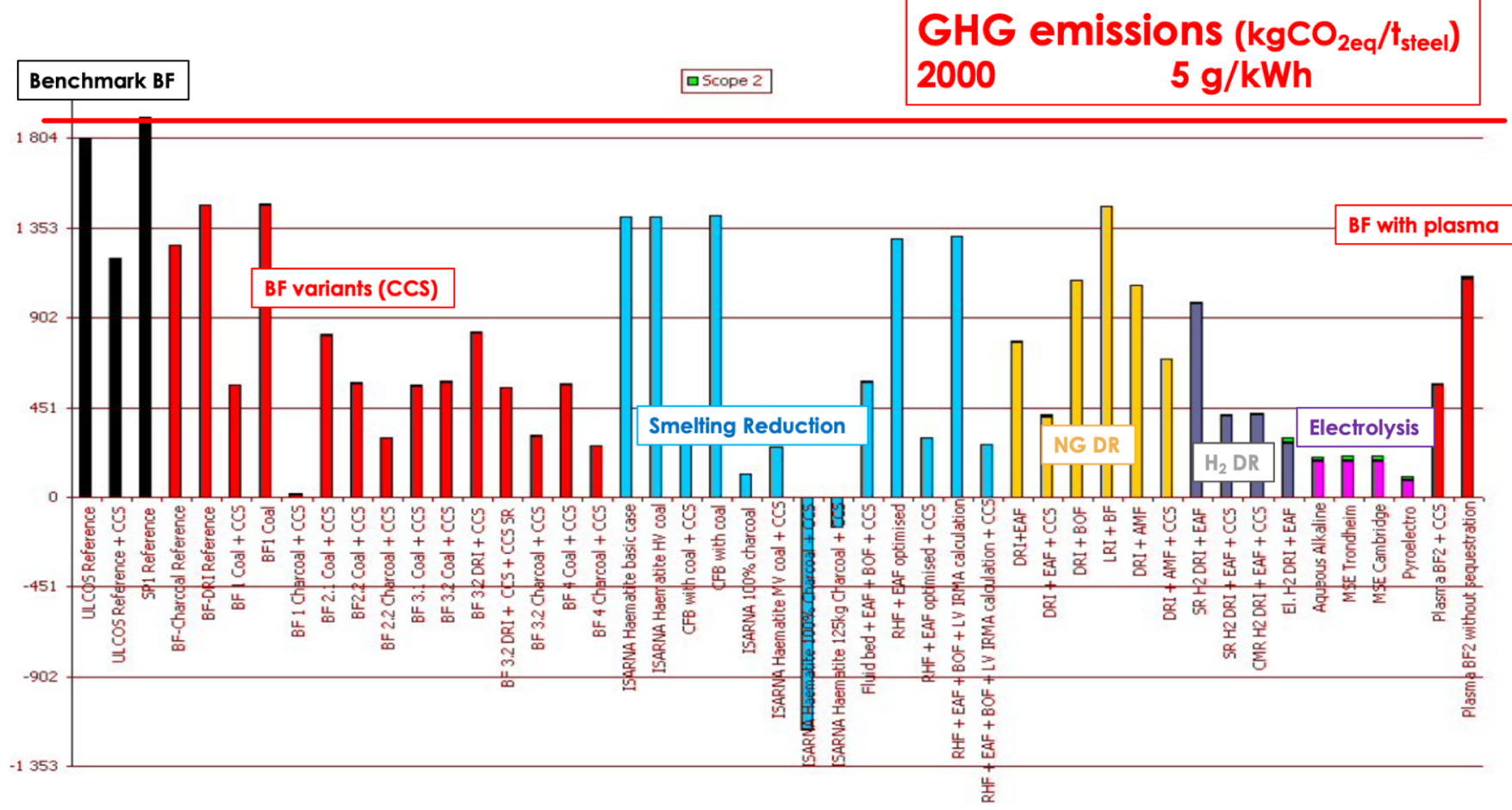

Fig. 6. $\mathrm{CO}_{2}$ emissions, $5 \mathrm{~g} \mathrm{CO}_{2} / \mathrm{kWh}$, nuclear power plant, 2000.

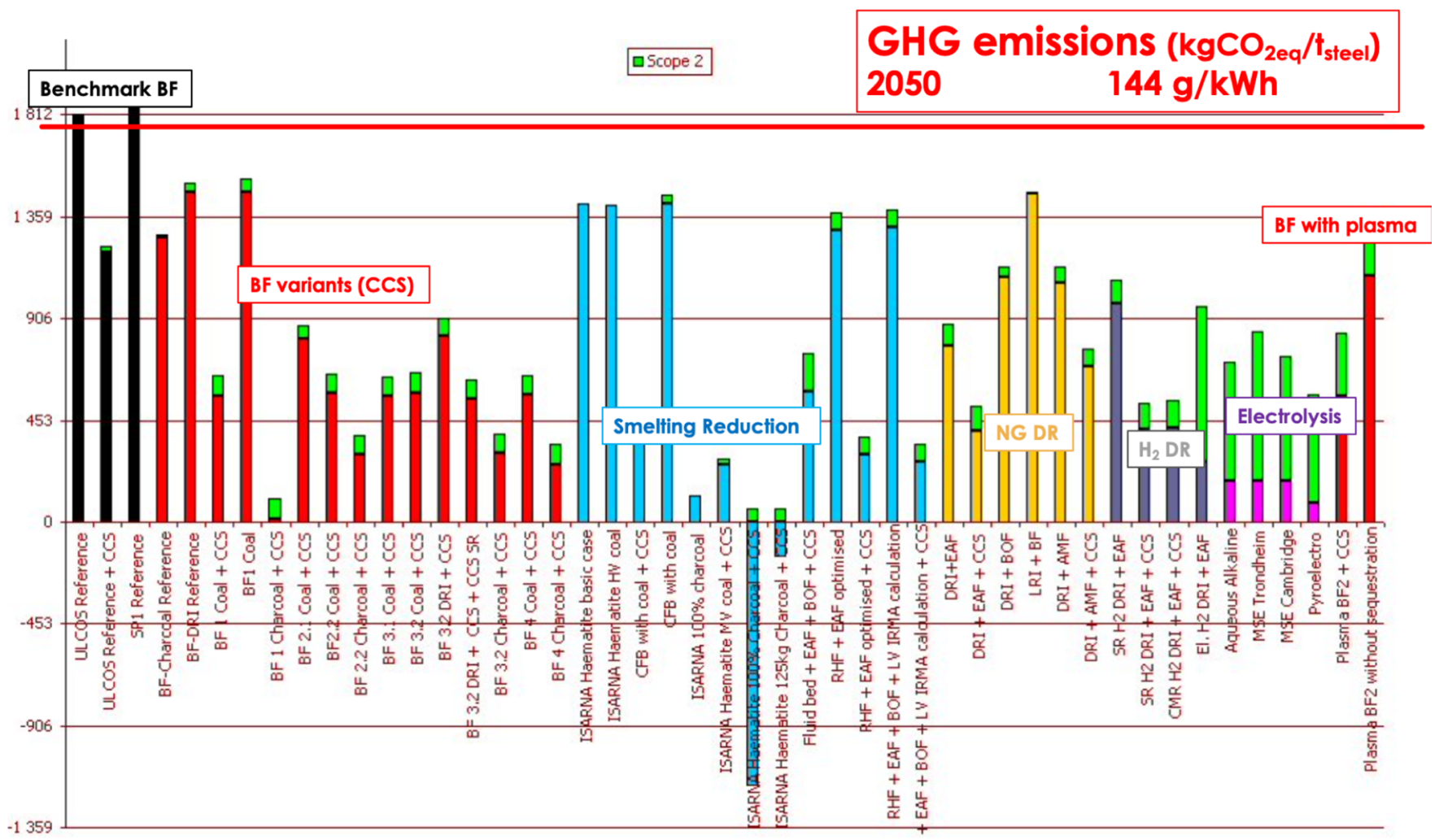

Fig. 7. $\mathrm{CO}_{2}$ emissions, "factor 4" scenario, $2050,144 \mathrm{CO}_{2} / \mathrm{kWh}$. 


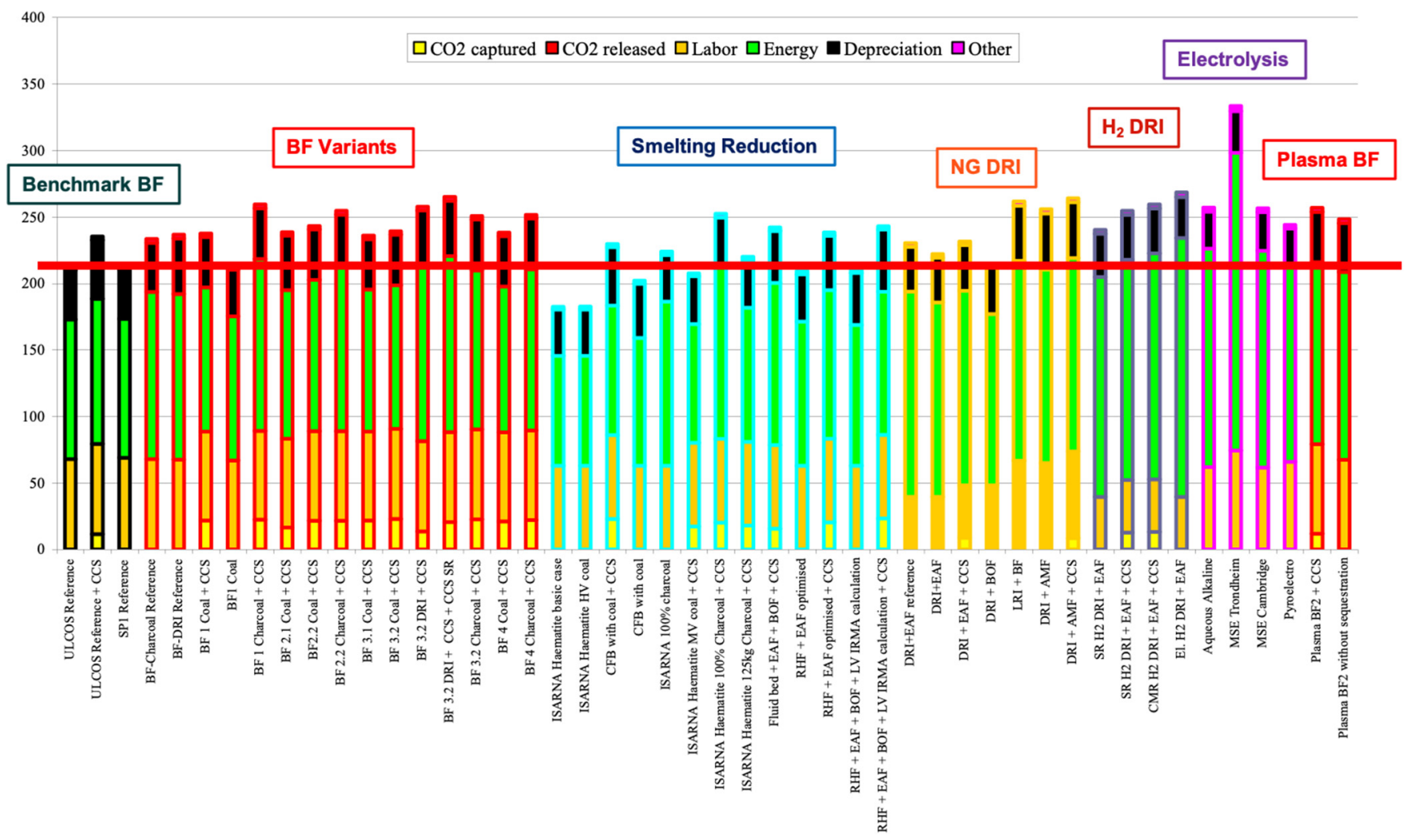

Fig. 8. Cost calculations, BAU scenario, 2000. Y-axis figures are an index.

routes, which have also been designed based on high efficiency. There is therefore not too much to expect in terms of energy efficiency improvement with the "new" breakthrough process routes!

- Figures 5-7 show GHG emissions. Results are much more spread out, which is normal as this was the point intended when examining all the new process routes. Scope I emissions are in color and scope II emission (mostly electricity) are in green. The first two sets of simulations are relative to year 2000, the base year of the study, with the European energy intensity of the electricity grid then and a nuclear power based grid, 370 and $5 \mathrm{~g}_{\mathrm{CO} 2} / \mathrm{kWh}$ respectively. The differences are entirely driven by two factors: use of CCS on the one hand and use of electricity on the other, with scope II emissions vanishing in the second scenario. See the original publications for an interpretation of each bar. For example, the negative emissions correspond to a case where biomass (charcoal) is used along with CCS-a result widely acknowledged by now. The "best" results in terms of emissions are shown in Figure 7: they show a factor 4 scenario (75\% reduction of emissions in 2050 vs. 2000 ), for which the grid carbon intensity was calculated at $144 \mathrm{~g}_{\mathrm{CO} 2} / \mathrm{kWh}$.

- Figures 8 and 9 show total costs (similar to an LCOS), a $B A U$ scenario in 2000 and a factor 4 scenario in 2050. Today, most breakthrough routes are more expensive than the benchmark BF route: there are no low-hanging fruits to pick up today to cut GHG emissions. However, in 2050, the tables have turned completely around and the benchmark BF (of today) is much more expensive than most alternative solutions, especially breakthrough ones. Exceptions are smelting reduction processes without CCS.

The next question that comes up is that of ranking the various process routes with respect to each other. The full comparison is discussed in Appendix A and in Figures A1-A4 [14].

Here, in the main text, we will only compare electricitybased routes, i.e., hydrogen and electrolysis, as they are more relevant to the topic of this article, cf. Figure 10.

Figure 10 shows $\mathrm{CO}_{2}$ emission - in a grid with either 370 or $5 \mathrm{~g}_{\mathrm{CO} 2} / \mathrm{kWh}-$, energy needs and total costs in 2000 , focusing on direct reduction from hydrogen produced by electrolysis of water (or steam) and aqueous, alkaline electrolysis of iron ore (ULCOWIN and SIDERWIN). In all categories, electrolysis seems to fare better than hydrogen: a simple argument would suggest that in the case of electrolysis of iron ore, the process is one step, while in the case of hydrogen, there are 2 consecutive steps, electrolysis of water and then gas reduction of ore pellets. However, the differences are small, well within the uncertainties of such simulations, and therefore better data, collected on demonstrators or plants to come would be needed to arrive at a clear answer. The least that can be said today, is that electrolysis of iron ore is a serious contender to hydrogen steel production, in spite of the hype that would seem to favor the hydrogen route, hic et nunc. 


\section{Cost of production LCOS $\left(\epsilon / t_{\text {steel }}\right)$ 2050 Factor 4 scenario}

$\square \mathrm{CO} 2$ captured $\square \mathrm{CO} 2$ released $\square$ Labor $\square$ Energy $\square$ Depreciation $\square$ Other

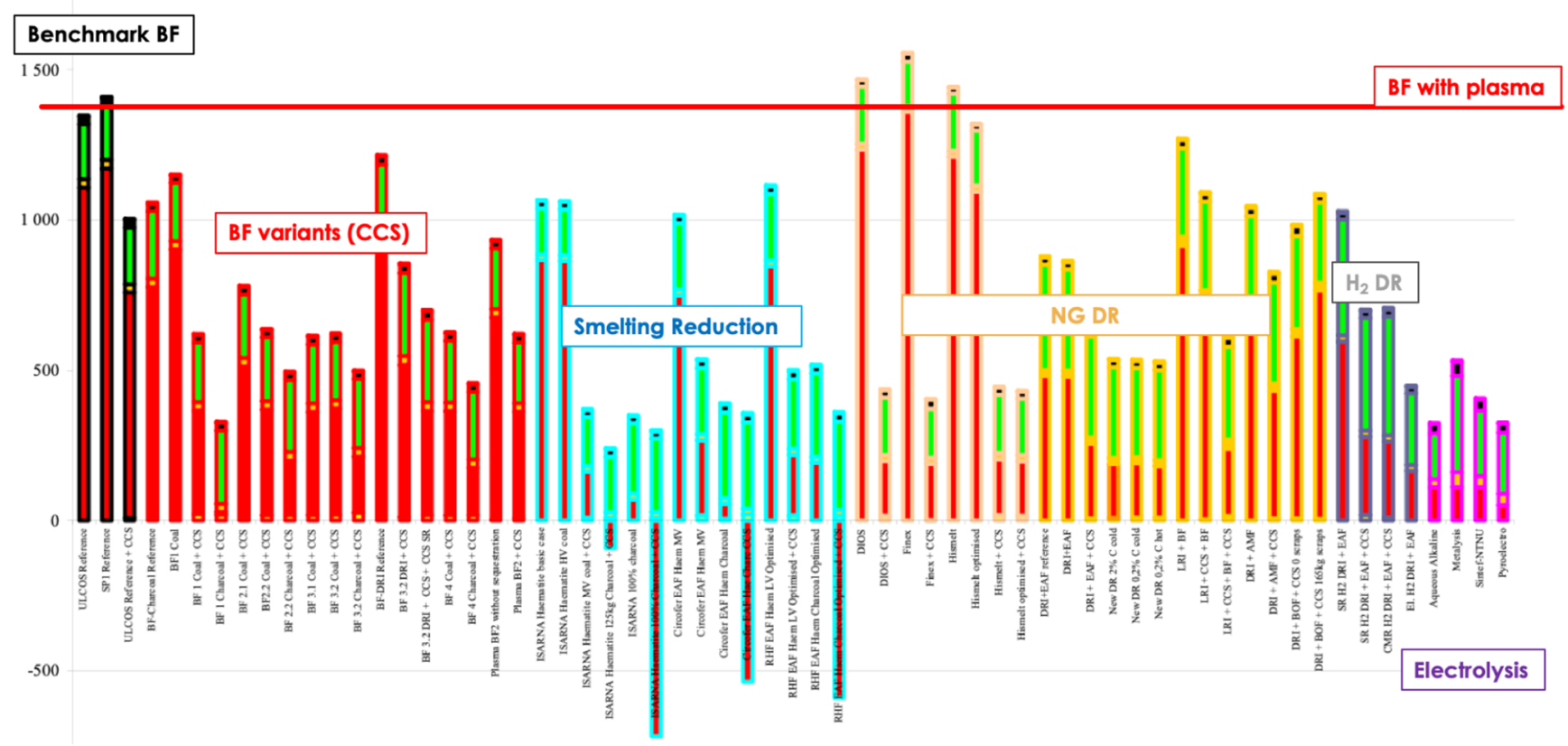

Fig. 9. Cost calculations, "factor 4 scenario", 2050. Y-axis figures ought to be considered as an index.
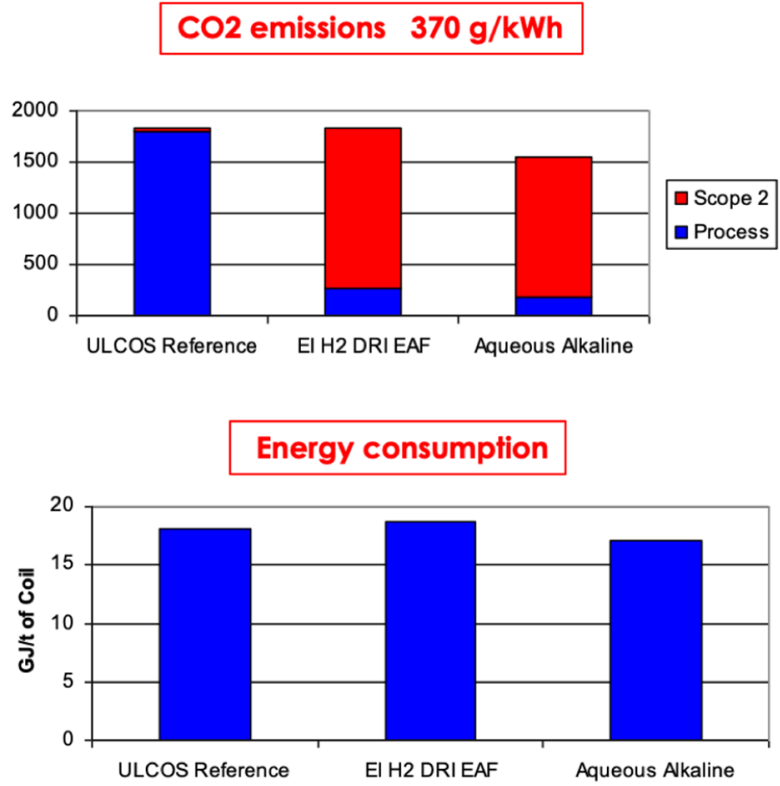

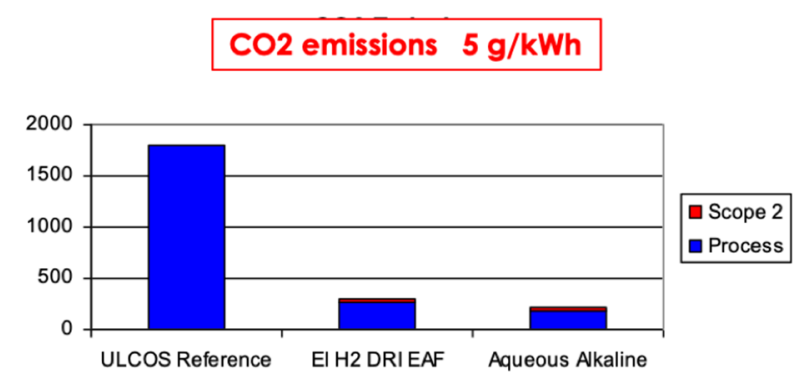

Cost of production $\left(€ / t_{\text {steel }}\right) \quad 2000$

- Labour $\square$ Energy $\square$ Depreciation

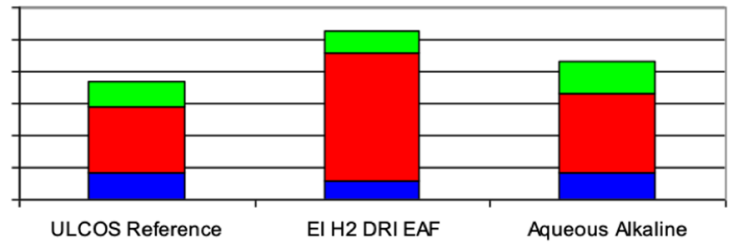

Fig. 10. Comparison of electricity-based hydrogen reduction and aqueous electrolysis [15].

As Appendix A and Figure 10 suggest, it would be somewhat presumptuous to believe that process route simulations can help identify which of the putative lowcarbon routes will end up as winners. As we will stress in the conclusion, it is likely that several routes will actually develop in parallel, reach industrial implementation and survive, side by side. This is what is happening today in the steel sector, where 3 major routes, holding each other at arm's length, coexist-integrated mill (IM), scrap-based electric arc furnace mill and DRI-based mill. In the not-sodistant past, there were even more production routes competing with each other. 
BAU

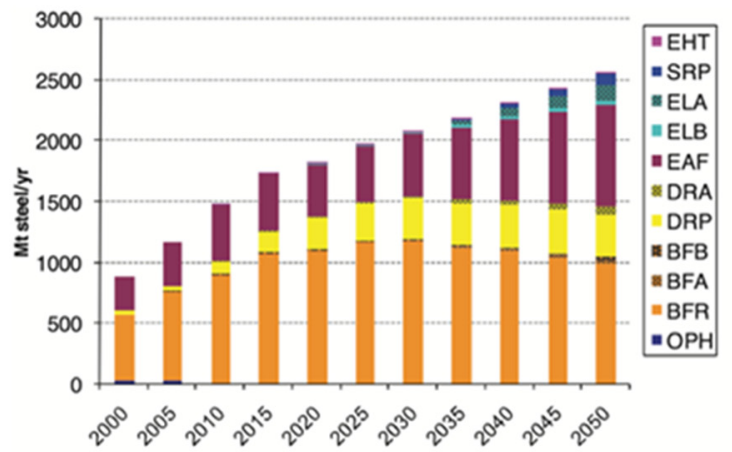

Strong carbon constraint

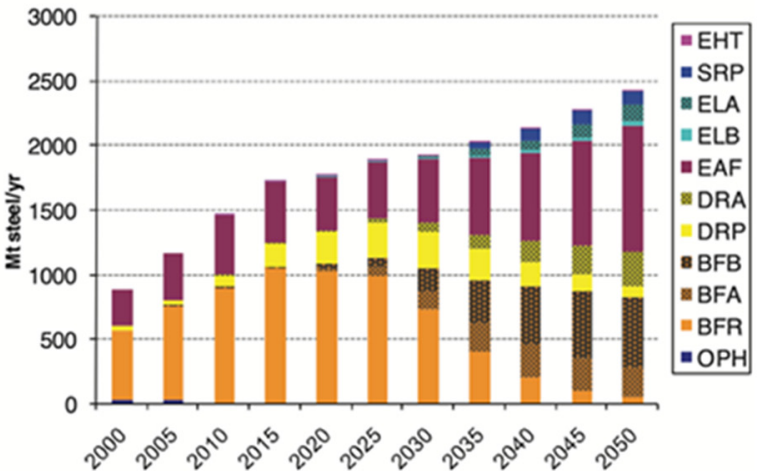

Fig. 11. Evolution of world steel production as a function of breakthrough technologies for a BAU scenario (left) and a World F2 scenario (right). Source [12]. See original article and list of acronyms for the definition of the various process routes, the proportion of which are followed as a function of time.

Another approach is to explore the possible evolutions of the various breakthrough process routes without assuming that a single process will grab the whole market share. Rather, the sector's futures would be a combination of all of them, which would develop in time depending on various factors which would privilege one and then another at some point in time. Figure 11 shows this type of scenario evolution for the various ULCOS technologies examined under a BAU scenario and one in which world emissions are divided by a factor 2 in 2050 (F2 World).

Various reviews of the ULCOS programs have been published, either by ULCOS partners [16-30] or by unrelated researchers [31-39]. Some of them have a wider scope than ULCOS and the steel sector. Moreover, further scenario studies were conducted beyond the ULCOS studies per se, e.g., [40-47]. A more detailed review paper would be needed to analyze all published information more extensively.

\section{Research and development work on low-carbon steelmaking and hydrogen-based processes}

Table 1 gives an overview of the efforts devoted to lowcarbon steelmaking, including hydrogen routes, since the first experiments conducted in the 1950s in the US. Exhaustively, however, is out of reach given the dynamics of the trend and the almost daily announcement of new projects.

We have organized the timeline in four periods:

- the period of historical experiments, H-Iron [48] and CIRCORED, driven by curiosity about hydrogen reduction and fluidized beds;

- the early 2000 s research effort, devoted to decoding what low-carbon solutions were possible to tackle the climate change challenge, already recognized as a threat at the time. This period led to the development of large international programs, wherein the efforts were mutualized among steel producers with substantial financial support from national or regional organizations. This period ended with the economic crisis, between 2010 and 2012: it saw the freezing of the most advanced and most promising of the ULCOS sub-project, the ULCOSBlast Furnace or TGRBF.

- the piteous years ${ }^{2}$, when the R\&I efforts slowed down significantly, both because of the crisis and of the need for financing institutions to reexamine and refocus their support (e.g., the NER 300 program of the EU [49] has become the Innovation Fund [50]). Most previous efforts continued, although at a reduced pace. This period stretched until the end of the 2010s.

- more recently, a consensus emerged about the need to act with determination to control climate change: the COP21 Paris agreement and the Green Deal Strategy of the European Commission, soon duplicated in other regions of the world, were the major reasons for a change of speed. This led to an explosion of project proposals, in response to financing opportunities for research and further industrial implementation opening on this topic, especially in the EU (HEU Program, Innovation Fund, etc.).

The expression "low-carbon" steelmaking changed over to "zero-carbon steelmaking" to mirror the vocabulary of the EC and now to Net-Zero. Business unions, such as EUROFER or ESTEP, declared almost overnight that their target was carbon neutrality by 2050. Business, especially the steel sector as a whole, came up with crafted declarations adopting the same carbon neutrality target as the EC for 2050, sometimes a bit earlier, something a bit later (Japan, China). Hydrogen, which had remained

2 This expression is usually used in connection with the 40 years that followed the high growth period, in Europe, called the (30) Glorious Years. It is used here to suggest a historical analogy, not to be derogatory in its meaning. 
Table 1. Projects and programs regarding low-carbon and especially hydrogen steelmaking since the 1950s.

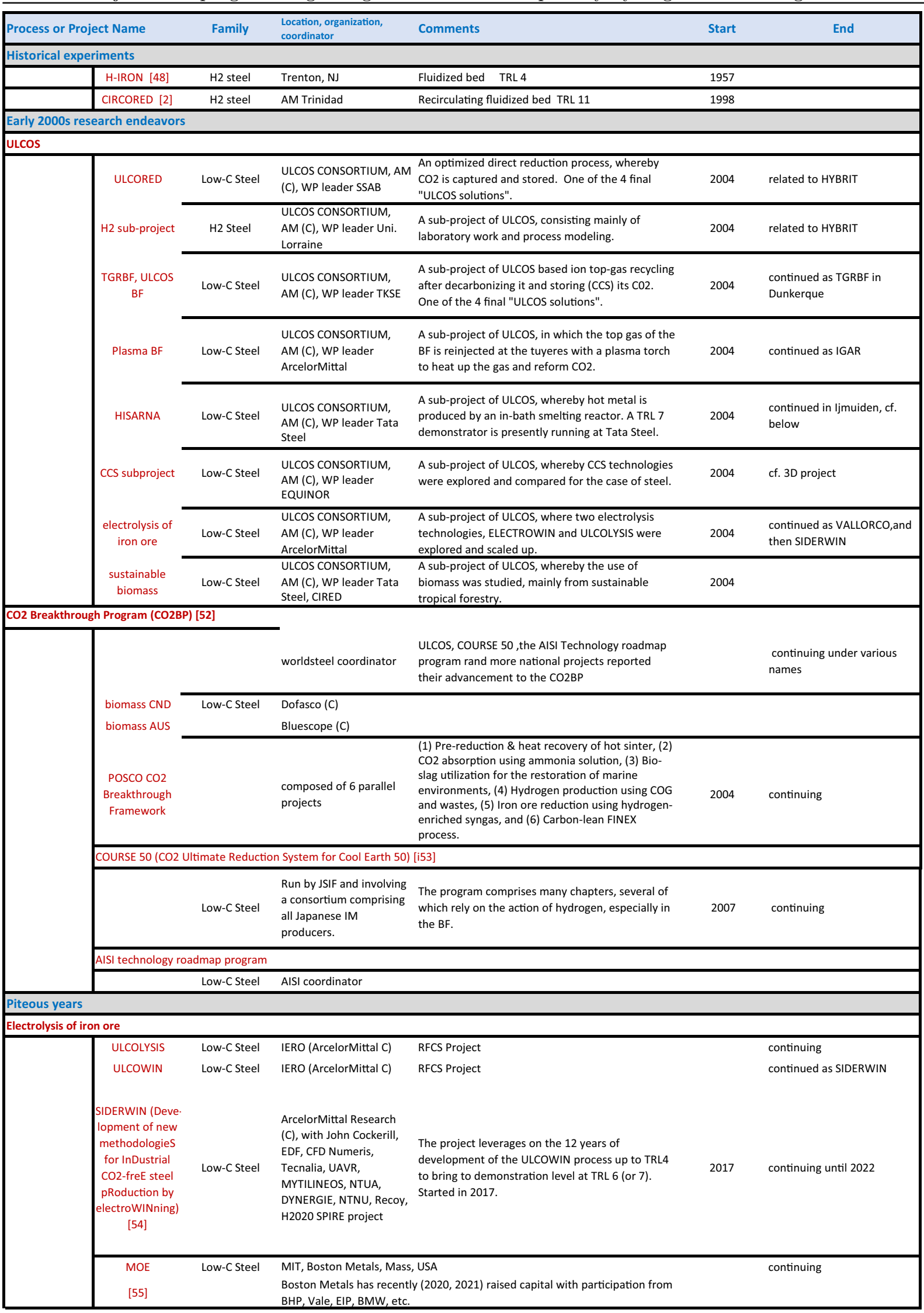


Table 1. (continued).

\begin{tabular}{|c|c|c|c|c|c|c|}
\hline \multicolumn{7}{|c|}{ Smelting Reduction } \\
\hline & HIsarna $[28,29]$ & Low-C Steel & Tata Steel Europe & $\begin{array}{l}\text { A demonstration plant, similar to a FOAK plant, has } \\
\text { been running in IJmuiden. Continuation of the } \\
\text { ULCOS program. }\end{array}$ & \multicolumn{2}{|r|}{ continuing } \\
\hline \multicolumn{7}{|l|}{ Blast Furnace } \\
\hline & VALORCO [56] & Low-C Steel & $\begin{array}{l}\text { ArcelorMittal \& } \\
\text { universities }\end{array}$ & ADEME funding. & 2014 & 2018 \\
\hline & $\begin{array}{c}\text { IGAR [57] } \\
\text { Injection de Gaz } \\
\text { Réducteur }\end{array}$ & Low-C Steel & $\begin{array}{l}\text { ArcelorMittal (C) with } \\
\text { EUROPLASMA, Basis, I2M, } \\
\text { Uni. Pau et pays d'Adour, } \\
\text { coRia, INP Toulouse }\end{array}$ & $\begin{array}{l}\text { ADEME Project, } 4 \text { years, finalized in 2018, } 21 \mathrm{M€} \\
\text { total budget }\end{array}$ & & $\begin{array}{l}\text { continuing from ULCOS WP } \\
\# 6\end{array}$ \\
\hline & Steelanol & & $\begin{array}{l}\text { ArcelorMittal (C) with } \\
\text { Lanzatech, PRIMETALS \& } \\
\text { E4Tech }\end{array}$ & $\begin{array}{l}\text { A biotechnology process in which bacteria reduce } \\
\mathrm{CO} / \mathrm{CO} 2 \text { into organic molecules. }\end{array}$ & & \\
\hline \multicolumn{3}{|c|}{ Recent steel endeavors - R\&I } & \multicolumn{4}{|c|}{ (steelmaking and/or hydrogen production or other processes) } \\
\hline \multicolumn{2}{|l|}{ SALCOS } & H2 steel & \multicolumn{4}{|l|}{$\begin{array}{l}\text { Salzgitter, DRI production } \\
\text { from } \mathrm{H} 2 \text { in a shaft furnace }\end{array}$} \\
\hline \multicolumn{2}{|l|}{$\begin{array}{l}\text { Utah University } \\
\text { FIT Process }\end{array}$} & H2 steel & $\begin{array}{l}\text { Smelting reduction, } \\
\text { hydrogen AISI \& DOE } \\
\text { support, University of } \\
\text { Utah (C) }\end{array}$ & A reactor concept based on flash smelting. & & \\
\hline \multirow{2}{*}{\multicolumn{2}{|c|}{ China shaft DRI from coal syngas }} & H2 steel & & & & \\
\hline & & & & $\begin{array}{l}10 ; 000 \mathrm{t} / \text { an demonstrator, fed by syngas: } 57 \% \mathrm{H} 2 \\
38 \% \mathrm{CO}\end{array}$ & & \\
\hline HYBRIT & $\mathrm{H} 2$ shaft $\mathrm{DR}$ & H2 steel & $\begin{array}{l}\text { Sweden, LKAB (C), SSAB, } \\
\text { Vattenfall }\end{array}$ & & & \\
\hline \multirow{2}{*}{\multicolumn{2}{|c|}{ GrInHy }} & & & & 2016 & \\
\hline & & $\mathrm{H} 2$ generation & Salzgitter (C) + 6 al. & $\mathrm{FCH}-\mathrm{JU}$ financing, steam electrolysis & & \\
\hline \multicolumn{7}{|l|}{ H2FUTURE } \\
\hline & & $\mathrm{H} 2$ generation & voestalpine & $\begin{array}{l}\text { FCH-JU financing. Yield: } 77.8 \% \text {. Wel } 48-51 \\
\mathrm{kWh} / \mathrm{kgH} 2.6 \mathrm{MW} \text { electrolyzer. 1,200 m3/h H2 \& } \\
600 \mathrm{~m} 3 / \mathrm{h} \mathrm{O2} \text {. CAPEX < 1,000 } € / \text { t. Funding: } 12 \mathrm{~m} € \text {. }\end{array}$ & & \\
\hline \multicolumn{7}{|l|}{ SUSTEEL } \\
\hline & & H2 steel & voestalpine & smelting reduction with an $\mathrm{H} 2$ plasma torch & & \\
\hline \multicolumn{5}{|c|}{ smelting reduction in a plasma flash smelter (HPSR: Hydrogen Plasma Smelting Reduction ) } & $\begin{array}{l}\text { Continuation of } \\
\text { SUSTEEL }\end{array}$ & \\
\hline & & $\mathrm{H} 2$ steel & voestalpine & smelting reduction with a $\mathrm{H} 2$ plasma torch & & \\
\hline Project 3D & & & ArcelorMittal Dunkerque & CO2 separation technology for CCUS & & \\
\hline \multicolumn{7}{|c|}{ Future DOE project on low-carbon steel } \\
\hline & & & DOE, USA, plan & $\begin{array}{l}\text { To be launched in } 2022 \text {, to be focused on } \\
\text { electrolysis and } \mathrm{H} 2 \text { flash smelting reduction }\end{array}$ & & \\
\hline \multicolumn{3}{|l|}{ TORERO } & $\begin{array}{l}\text { ArcelorMittal Ghent, with } \\
\text { TORRCOAL, RENEWI, } \\
\text { Chalmers U., Joanneum } \\
\text { Research, Uni Graz }\end{array}$ & $\begin{array}{l}\text { TOR refying wood with Ethanol as a Renewable } \\
\text { Output. Large-scale demonstration: converting } \\
\text { wood waste to biocoal. Ethanol from the Steelanol } \\
\text { plant on the same site. }\end{array}$ & $\begin{array}{l}\text { Ground- } \\
\text { breaking in } \\
02 / 2021\end{array}$ & \\
\hline \multicolumn{3}{|c|}{ Coking gas injection BF } & $\begin{array}{l}\text { HKM with Paul Wurth } \\
\text { technology }\end{array}$ & & & \\
\hline \multirow{2}{*}{\multicolumn{2}{|c|}{ Coking gas injection $\mathrm{BF}$}} & $\mathrm{H} 2$ injection $\mathrm{BF}$ & ROGESA, Germany & & 2020 & \\
\hline & & & ROGESA, Germany & & 2021 & \\
\hline \multicolumn{3}{|c|}{ PEM (Primary Energy Melter) [58] } & ArcelorMittal Gent & $\begin{array}{l}\text { Melting of steel scrap using gas \& } \mathrm{O} 2 \text {, to be added } \\
\text { to hot metal in a torpedo car. SMS technology. }\end{array}$ & & \\
\hline \multicolumn{3}{|l|}{ CARBON2CHEM } & $\begin{array}{l}\text { TKS }(\mathrm{C}) \text {, ArcelorMittal, } \\
17 \text { partners }\end{array}$ & Erected in Duisburg, H2020 SPIRE project. & 2018 & \\
\hline CARBON4PUR & & & $\begin{array}{l}\text { Dechema, ArcelorMittal, } \\
\text { CEA, RWTH, TU Berlin, } \\
\text { Marseille-Fos, South Pole, } \\
\text { Megara Resins, Uni. Gent, } \\
\text { Uni. Leiden, COVESTO, } \\
\text { RECTICEL }\end{array}$ & $\begin{array}{l}\text { H2020 SPRE project. development and } \\
\text { demonstration of a new flexible technology for the } \\
\text { production of value-added chemicals, polyester } \\
\text { polyols, of carbon derived from steel mill gas. }\end{array}$ & 2017 & 2021 \\
\hline
\end{tabular}


Table 1. (continued).

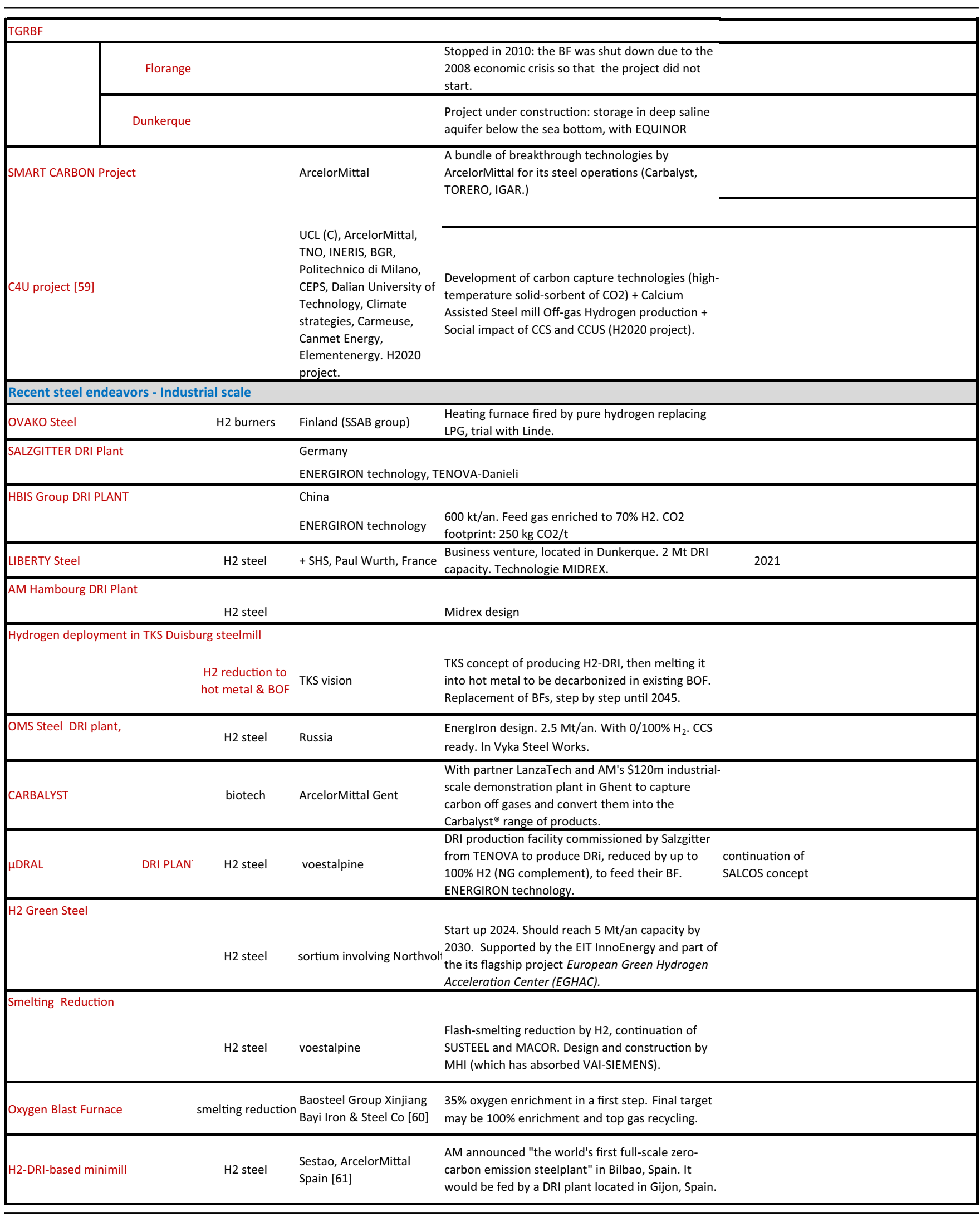


Table 1. (continued).

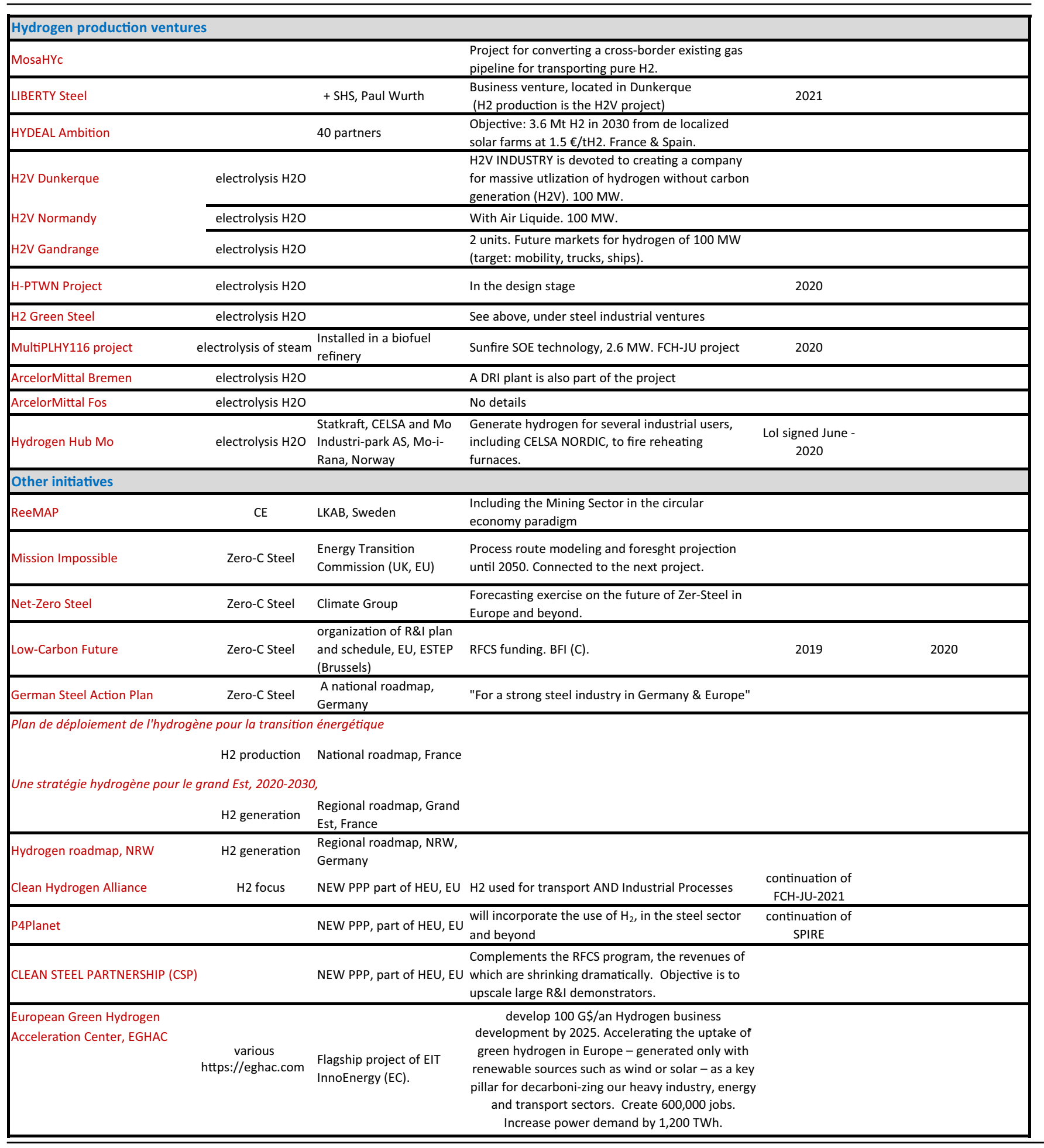


Today

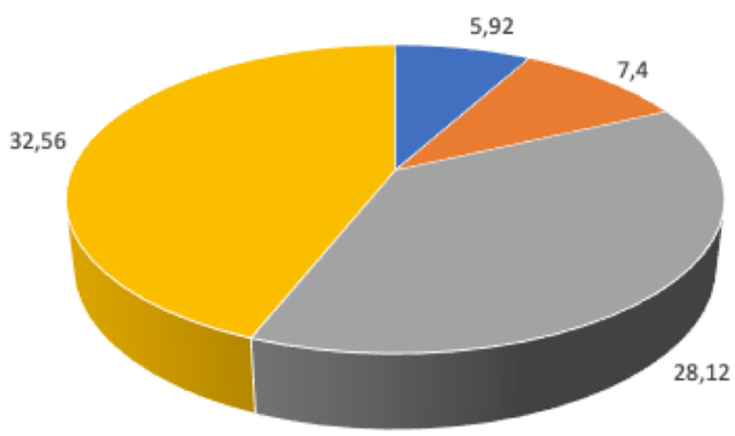

- other chemicals = msicellaneous = ammmonia = refining
In the future (?)

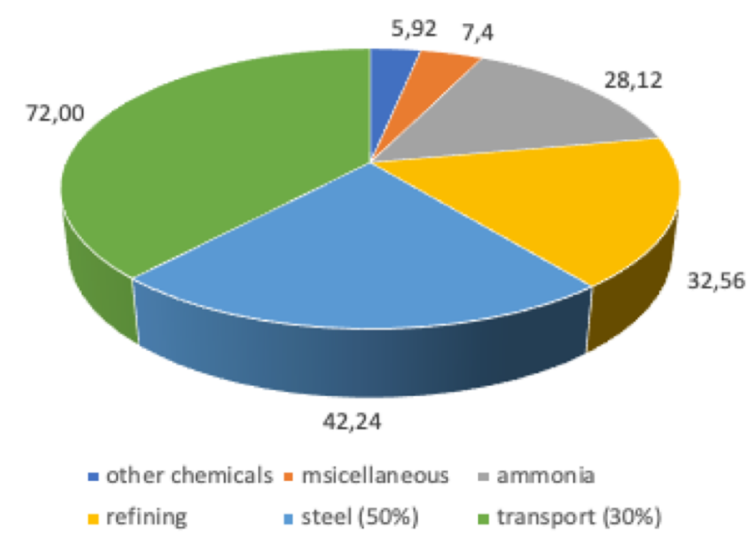

Fig. 12. Proportion of hydrogen (\%) used today (left) and projection assuming use in transport (30\%) and in steel production $\left(50 \%-700 \mathrm{Nm}^{3}{ }_{\mathrm{H} 2} / \mathrm{t}_{\mathrm{Fe}}\right)$ (right).

low-key until then, came to the forefront and became the darling of strategic planners and policymakers, with Germany and France calling the shots.

Content-wise, beyond the historical timeline, we distinguished a series of business ventures, focused either on hydrogen steelmaking (Recent steel endeavors - Industrial scale) or on the production of hydrogen, with large hydrogen-guzzling potential applications as steelmaking in mind (Hydrogen production ventures). Finally, a large number of studies have started to come out to paint the scenarios for the switch over from today's steelmaking to future, breakthrough steelmaking, with sufficient room given to hydrogen (Other initiatives). A mention to silicon is added there, although it does not strictly belong to a discussion on steel, as the approach is very similar (carbon neutrality by 2050, CCS applied to a smelting furnace) [51].

\section{Comparison of hydrogen markets to come}

Present or future users of hydrogen have tended to function in silos: for example, interaction between users in fuel cells and in steel direct reduction have been rather limited. Beyond these two areas, for example the refining or the chemical sectors, or the future concept of incorporating hydrogen with $\mathrm{CO}_{2}$ captured from industrial processes, the interaction has been even more diaphanous!

The world production of hydrogen in 2018 was $74 \mathrm{Mt} /$ year. $44 \%$ was used in the oil refining industry (to cut the molecular weight of heavy oil), $38 \%$ to make ammonia (and, further on, fertilizers), $8 \%$ to make other chemicals (amines, methanol, hydrogen peroxide) and $10 \%$ for miscellaneous applications (space, glass industry, food industry) [63].

Among the emerging uses of hydrogen, the most emblematic ones are transport and steel production. However, there are further options being considered, like transporting hydrogen overseas to fire power plants or for other uses (Japan, from Australia).
$\mathrm{H}_{2}$-transport means one or several electric motors coupled to a fuel cell and powering automobiles, heavyduty vehicles, ships, trains and even aircrafts. There are 1.2 billion vehicles in the world, renewed at the rate of 90 million per year. A light vehicle runs for $100 \mathrm{~km}$ with $1 \mathrm{~kg}$ of hydrogen. Assume $20000 \mathrm{~km} /$ year for each one of them. If $10 \%$ of the world fleet ran on hydrogen, then the need would be for $24.1 \mathrm{Mt} /$ year. At $30 \%$, the total present volume of hydrogen production would be needed for transportation. Converting the whole fleet to hydrogen would need 3 times the world production today.

Steel needs between 590 and $700 \mathrm{Nm}^{3}{ }_{\mathrm{H} 2} / \mathrm{t}_{\mathrm{Fe}}$. Producing $10 \%$ of the steel world's production (1867.5 Mt in 2019) by hydrogen direct reduction would require $11.75 \mathrm{Mt}_{\mathrm{H} 2} /$ year, the total steel production $95.7 \mathrm{Mt}_{\mathrm{H} 2} /$ year [64].

Figure 12 shows the distribution of usage in the present scenario and in the future one, where hydrogen is assumed to account for $30 \%$ of transport needs and $50 \%$ of steel production needs.

Both estimates are rough, back-of-the-envelope calculations ${ }^{3}$. However, they show that transport and steel under such circumstances would require the same order of magnitude of hydrogen amount and that this number compares with the world production today. This demonstrates the magnitude of the foreseen applications and the major transformation of the hydrogen sector that this would involve.

Today, $96 \%$ of hydrogen is produced by steam reforming (SR) of fossil resources (49\% from natural gas, $29 \%$ from oil and $18 \%$ from coal), the rest being natural $\mathrm{H}_{2}$ trapped in geological reservoirs ${ }^{4}$. In the future, the vision is to use green or renewable hydrogen, mostly generated by electrolysis of water using green or renewable electricity.

3 The estimate is not exactly a projection into the future: new market for $\mathrm{H}_{2}$ are assumed, but the context is kept identical to today's.

4 It is actually a kind of fossil fuel, wherein carbon and hydrogen got separated. 


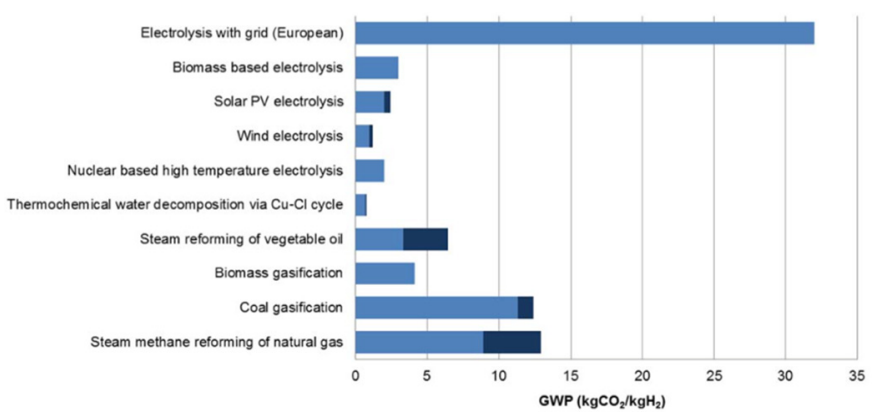

Fig. 13. A range of GWP for different hydrogen production schemes [66]. The black region shows the spread of data.

Assuming a conservative ratio of $60 \mathrm{MWh} / \mathrm{t}_{\mathrm{H} 2}$, this means, for the steel production taken on board in Figure 12, $2871106 \mathrm{GWh} /$ year or the equivalent of $470 \mathrm{EPR}$ nuclear power plants $(1700 \mathrm{Mw})$ or 80000 offshore wind turbines (OFWT).

Whether this scenario is possible from various standpoints (financing, erection calendar, social acceptance) remains an open issue: in particular, it should be weighed against competing technologies and, for example, CCS, the importance of which is often minimized by the claim that CCS would not encounter social acceptance [65].

It is also raising the issue of the massive electrification of the economy, that would be required if this solution was chosen as a privileged path towards introducing large amounts of renewable energy in the energy mix.

\section{LCA of hydrogen production - LCA of $\mathrm{H}_{2^{-}}$ based steel production}

The criteria used in this paper to estimate the impact of the use of hydrogen have been focused on GHG emissions and energy use in ULCOS. A more thorough analysis would have to use the LCA framework-thus extending the number of criteria taken on board-and possibly other methodologies like $M F A$.

Bhandari et al. carried out a literature review of $21 \mathrm{LCA}$ studies [66]. They provide the balanced view that is expected of LCA methodology.

Figure 13 shows that the GWP of hydrogen produced by electrolysis of water depends much on the carbon footprint of electricity. For example, using the European grid at the time, the footprint is more than twice as much as the contemporary technological state-of-the-art benchmark of SMR. On the other hand, green electricity, nuclear power or (sustainable) biomass does perform at much lower levels, as was to be expected.

Figure 14 shows that the Acidification Potential (AP) is similarly better with low-carbon electricity, except for biomass-based generation, which is definitely worse.

These results match the intuitive view that hydrogen stemming from green electricity should itself be greener. The contribution is mainly from wind turbines (solar was not included in that rather old study) rather than the electrolyzer. However, other indicators do not necessarily concur, but Bhandari did not review them.
For example, Simons and Bauer [67] study hydrogen in connection with transport in light-weight vehicles and states that: "An exception would be with regard to the emissions of PM10 for which all $\mathrm{H}_{2}$ pathways perform worse than the ICE fuels". Reviewing more recent work describing PM0.5 emissions would be helpful.

This caveat is a serious matter, as green hydrogen production might seem to be facing a conundrum due to particulate emission, in addition to the material paradox. PM emissions have a very strong impact on human health (premature deaths) [30] and therefore are worthy of attention.

If one looks at hydrogen for steel production, a lot of LCA studies are underway, as they are required by funding organizations, but very few have been published yet [68]. And they may be mostly taken for granted, as a kind of footnote to the study: not too many authors seem to have factored in the fact that LCA might flash red lights at some particular technology.

\section{A vision of future hydrogen steel production (and other zero-carbon routes)}

\subsection{A vision of hydrogen steel production and other routes in the future}

There are various issues that need discussing about hydrogen steel production: they are related to scale, disciplinary-wise. Indeed, there is:

- the microscale of physical chemistry phenomenology,

- the mesoscale of process engineering, at reactor level,

- the macroscale of technology development expressed in TRLs, with TRL 12 standing for industrial production plants and being the final target,

- and then the megascale of rolling out the technology (-ies) until it makes a measurable difference and actually reaches the zero-emission final target for the whole European steel sector by 2050 .

The microscale analysis is left out of the present discussion. See specialized articles [21].

What is expected from authors in this area is to estimate expected progress in terms of energy (and exergy) efficiency and hydrogen consumption/ton of $\mathrm{H}_{2}$-DRI-HBI. They should also formulate advice regarding the design of the reactor, especially of the shaft furnace.

\subsection{Process reactors for hydrogen reduction in the steel sector (mesoscale)}

The mesoscale is also out of scope for the present article, at the granularity that experts in the field would need. See the same references as in the previous paragraph. However, one might make a list of possible process reactors and stress some of their features:

- the shaft reactor, similar to what is most commonly used in the direct reduction processes based on natural gas (MIDREX-NG [69] or ENERGIRON, formerly HYLSA [70]). Not surprisingly, Midrex is collaborating for example with ArcelorMittal to erect a demonstration plant in Hamburg, Germany, called MIDREX-H ${ }_{2}$, where the 


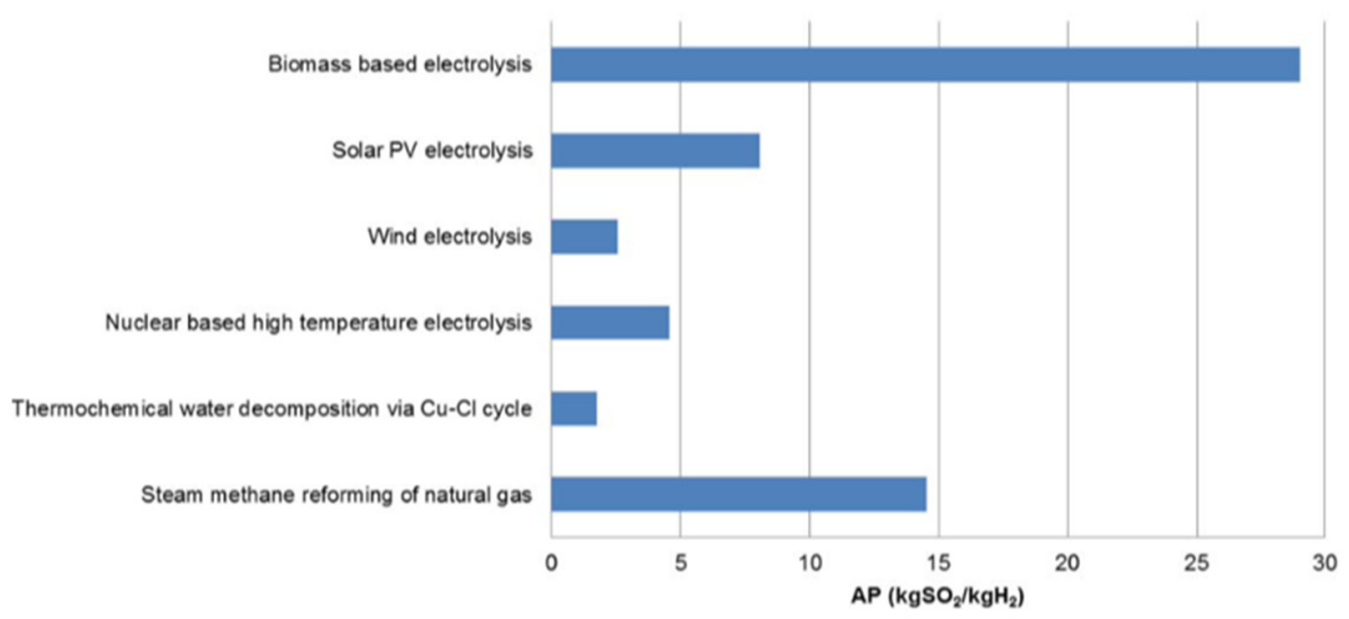

Fig. 14. A range of AP for different hydrogen production schemes [66].

design duplicates that of the $\mathrm{NG}$ reactor. It is not completely clear, yet, if the reactor will indeed work on pure hydrogen or on a mixture of $\mathrm{H}_{2}$ and natural gas, i.e., syngas. According to Patisson [21], a pure $\mathrm{H}_{2}$ operation could rely on the better reducibility of $\mathrm{H}_{2}$ and therefore implement a squatter design, both shorter and thinner. HYBRIT is also planning to rely on a shaft reactor [71-73]. This is probably the most likely personification of $\mathrm{H}_{2}$ direct reduction in the future, because the shaft reactor has proven to be the most reliable process technology, with the largest number of industrial references for gas reduction.

- the fluidized bed reactor, either bubbling or recirculating bed, was used in the early attempts at developing hydrogen reduction in the laboratory $[2,47]$. A complex technology, difficult to fine-tune, the fluidized bed is likely to continue sparkling interest in the research community but not with investors or decision makers.

- the flash reactor, quite common in copper production but hardly used in the world of steel, is at the core of the technology developed at Utah University. It is still a research tool, attractive because of the high kinetics that the operation at very high temperatures makes possible.

- the smelting reduction process studied in Austria is intermediary between flash smelting and in-bath smelting (such as the HIsarna process). Like the previous reactor, it should still be considered as a concept under investigation by research.

\subsection{Long-term scenarios for hydrogen prereduction and competing processes (macro- \& mega-scale)}

The macro- and mega-scales examine foresight scenarios, such as Figure 11 [12].

First, what is most likely is that there will not be a single technology route that will pick up the whole deal: a basket of solutions will remain at the core of these future scenarios. Therefore, there will remain the distinction between ore and scrap-based routes, but the ore-based route will be split among a series of technologies, electrolysis, hydrogen and blast furnace (with CCS and therefore most likely with CCS and top-gas recycling, TGRBF). An educated guess, published in [74], gives the following distribution: $70 \%$ for the EAF route, $30 \%$ for the iron ore route, within which $10 \%$ will come from the TGRBF, $10 \%$ from hydrogen direct reduction and $10 \%$ from electrolysis.

Note that the requirement for hydrogen is much less than what was envisioned in Section 5 (10\% vs. $50 \%$ ). This also holds true for electricity needs.

A more detailed scenario evolution is shown in Figure 15. It is a simple extrapolation of the intuitive 2100 targets given above. The scrap fraction evolves linearly with time and is assumed to be identical to the EAF route, which, by 2050, will have become carbon-neutral because the electric grid will be. All routes are supposed to be carbon neutral by 2050, so that the driver for scenario evolution is the availability of steel scrap. By 2030, the economy is assumed to be $2 / 3$ of the way towards carbon neutrality. This explains the kicks in the curves in 2030 and 2050. Electrolysis and hydrogen are assumed to progress in parallel, exactly at the same fraction. Some natural gas production (Direct Reduction) has been introduced in the scenarios and adjusted to roughly $10 \%$ of the BF route. By 2050, both BF and DR have turned carbonneutral by the implementation of CCS with geological storage of $\mathrm{CO}_{2}$.

\subsection{Financing for zero-carbon steel production}

How to finance research, up to TRL 9 and then 12, is the next issue related to macro and megascale analyses. The timeline for the scale up, scenario-wise, is also part of this step.

Financing issues are discussed extensively, especially in Regional contexts like the EU. There are projects looking specifically at this issue, for example the "Green Steel for Europe" project commissioned by the EC [75].

Financing is needed for research, for first industrial implementation and for deployment of technologies. 


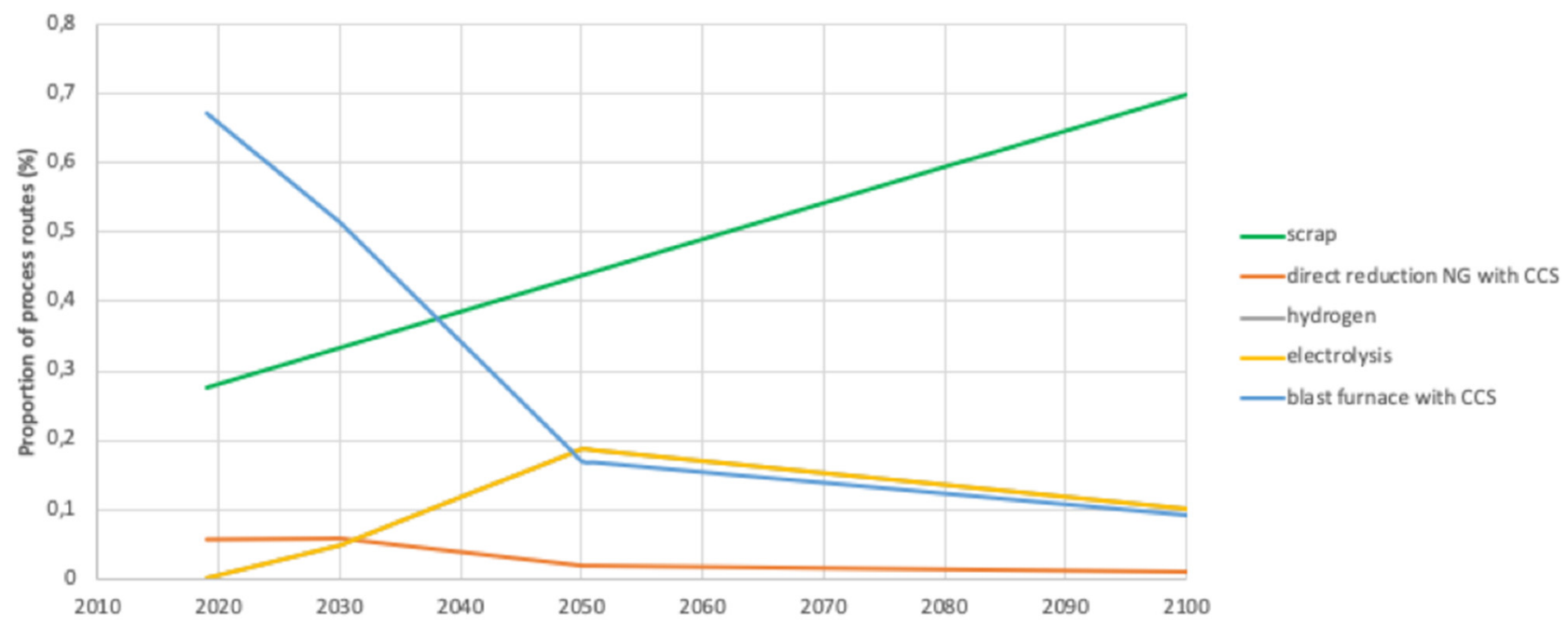

Fig. 15. Scenario for steel production in the 21st century. Carbon neutrality is reached in 2050, but scrap generation keeps replacing the iron ore routes to reach $70 \%$ capacity by 2100 . Note that the lines for electrolysis and hydrogen reduction are superimposed. Source: own work.
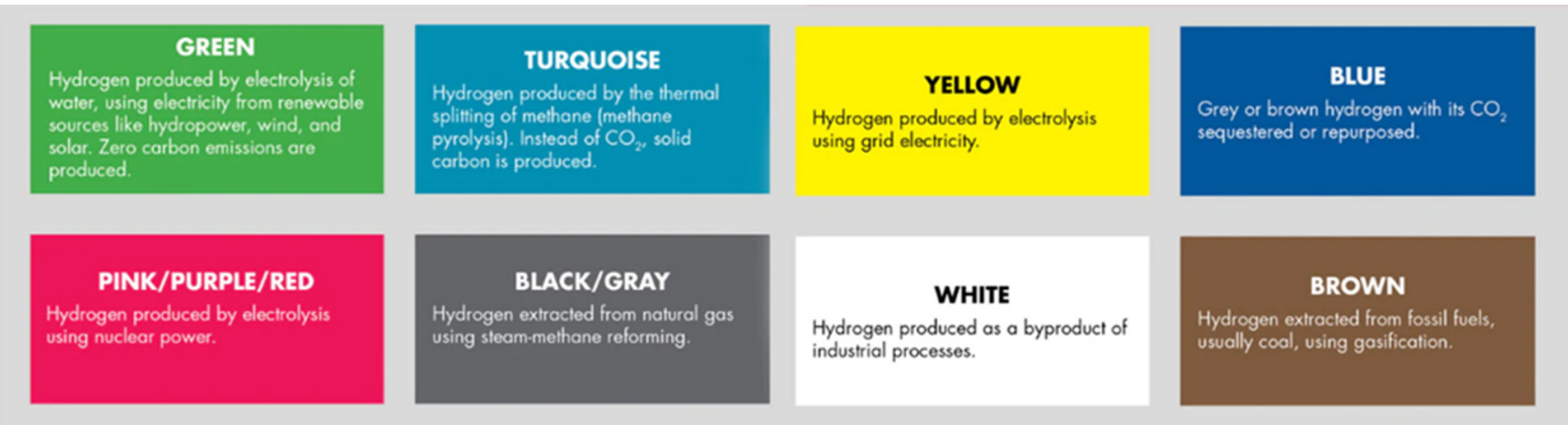

Fig. 16. "Colors of hydrogen", according to the sources of energy used for its production. The focus is on renewable or non-renewable energy and high or low-carbon footprint of the kWh.

Some of the financing ought to involve subventions and loans from government and regional organizations like the EU (RFCS, HEU, Innovation Fund, IPCEI projects, national funding) and from other sources like banks and private investors, providing either loans, equity participation or green bonds, etc. A certain amount of fuzziness is related to the fact that whereas support to R\&I is considered as normal, support for industrial implementation is not, even though the matter of financing low-carbon solutions is not settled and therefore requests for indefinite subventions might be on the table ${ }^{5}$. The talk is about an evanescent business model for running these experiments and market uptake. The financing scale ranges from a few billion euros for REII to several hundred for implementation.

\footnotetext{
5 The issue is hardly discussed in the STEM community in which the author is functioning, except as innuendos. There is a tension between an economic liberal vision, where business is supposed to be run according to standard neo-classical economics, which delivers "optimal" solutions automatically, and another one where government intervention is demanded by most players, including business, through either subventions or the setting of rules that would internalize the climate constraint.
}

\subsection{Sources of hydrogen and of electricity}

Where does electricity originate from in the scenarios examined here? Or, more generally, where does hydrogen originate from?

There is a tradition of attributing colors to both of them, which comes in handy, cf. Figure 16, although the habit seems to be waning [76].

Let's concentrate first on processes for producing hydrogen [77].

The most common method, today, is the steam reforming of natural gas (SMR), the technology used in direct reduction by Midrex for example, which generates hydrogen at a cost of $1.5 € / \mathrm{kg}_{\mathrm{H}_{2}}$ at the plant's gate [69]. The second one is the pyrolysis of fossil fuels, natural gas, oil and also coal: this takes place in a POx reactor, for Partial Oxidation. Both belong to the category of reformers, where a hydrocarbon molecule is broken by heat. Hydrogen can also be produced from biomass, which under controlled condition can be considered as renewable, and by electrolysis of water (or steam), a minority process today because of the price of electricity, but which is expected to become the major route to produce green hydrogen in the 


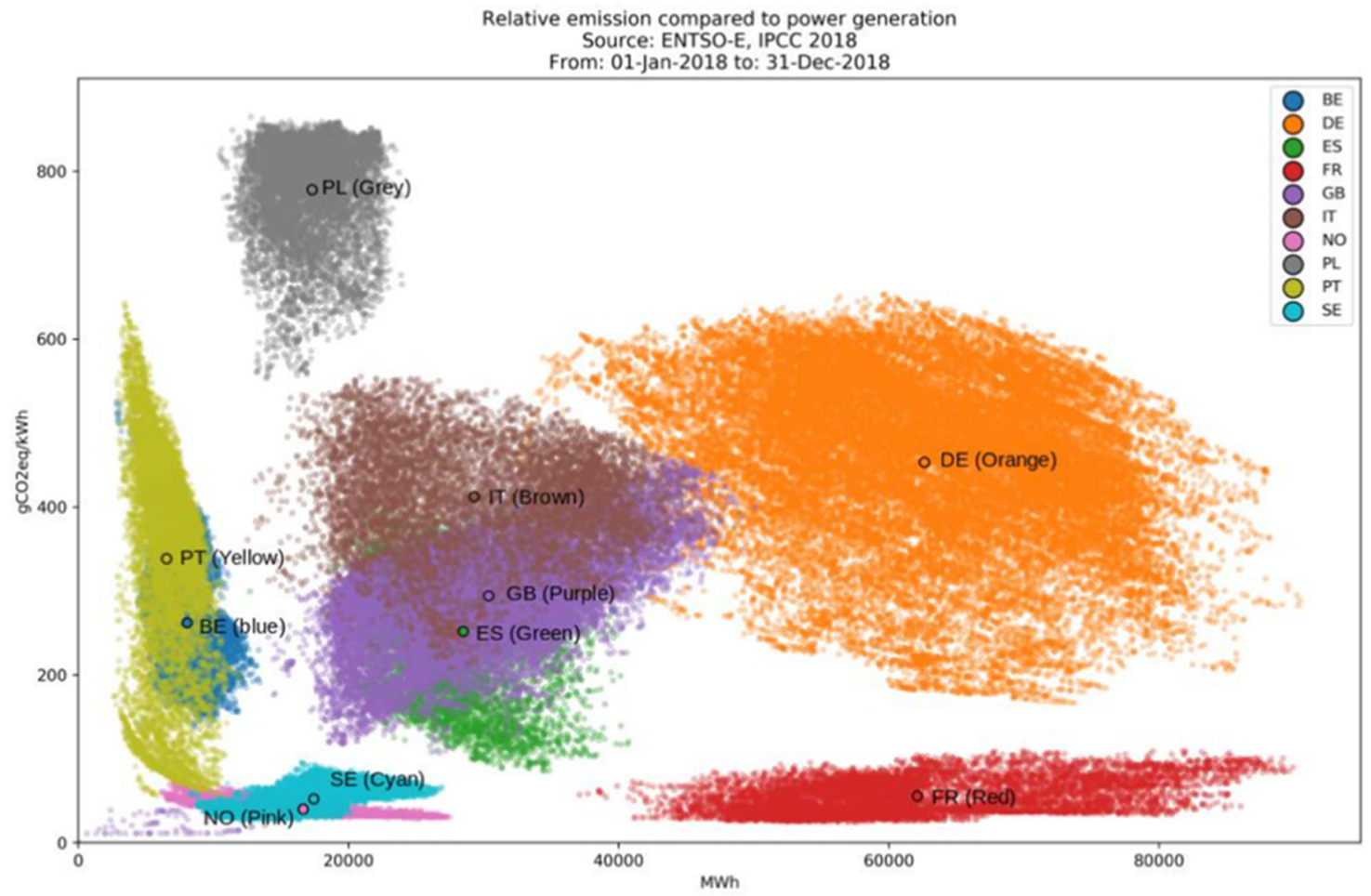

Fig. 17. Relative $\mathrm{CO}_{2 \text { eq }}$ emissions per kWh of national grid in Europe, showing actual emission over a 1-year period (2018) [83].

future due to the drop of REN prices (solar power and offshore wind farms). Emerging technologies include the production of hydrogen by microalgae or bacteria and water splitting using thermochemical cycles.

Most on-going industrial projects and research articles emphasize the use of renewable energy in the sense of REN electricity, while a few do low-carbon sources, like nuclear power, i.e., fission power plants. Last, there is some native hydrogen, already available and exploited by the gas industry, but possibly more to come [78]: projections still seem unclear.

One topic however, which is often dismissed, is fusion power generation: the 2050 roadmap for decarbonizing the US economy, however, takes it fully into account [79]. The wager consists in positing that the ITER project will be successfully completed by 2030 and therefore that the deployment of that technology will by then be in order, with all the advantages of fission nuclear power and none of its drawbacks. Note that smaller, privately-funded fusion projects are also being launched [80]. Fission would be a game changer, calling for a radical reformulation of the thinking about zero-carbon and hydrogen economies.

Let's discuss for a while the assumption that renewable electricity is indeed available and can be appropriated by hydrogen producers. It is an easy assumption to make in economic simulations, but, in practice, what is available from a power line is grid electricity, the carbon intensity of which is rarely zero [81]. Thus, examples by country is: Norway $11 \mathrm{~g}_{\mathrm{CO} 2} / \mathrm{kWh}$, Sweden 12, Austria 14, France 47, UK 277, USA 432, Germany 469, Poland 846, Japan 492, China 624, India 743, etc. The spread of actual values of emissions, over the whole year 2018, is shown in Figure 17 as a function of power output, country and mode of production according to its color (grey, yellow, blue, brown, purple, green, orange, cyan, pink and red).

Can the assumption of access to REN be taken for granted or should it be seen as a sleight of hand? There is the rare case where a small grid, entirely fed from RENs and not interconnected to a larger one, would be devoted to making hydrogen: then the assumption would be strictly correct. Refereeing to a national grid might look like a more reasonable assumption: however, the grids are strongly interconnected in Europe so that the regional carbon footprint is $275 \mathrm{~g}_{\mathrm{CO} 2} / \mathrm{kWh}$ [82]. Another layer of uncertainty is related to the fact that emissions are usually accounted at the gates of the production facilities, while it might be more meaningful to use an LCA estimate (see Sect. 6).

A solution proposed to solve this conundrum are green certificates (GC) (Renewable Energy Certificates or REC, Guarantees of origin) [71], i.e., financial instruments designed to "sell" green electricity to users who are prepared to pay an extra price beyond the market price of the local grid electricity. Prices on the US market have been fluctuating between 15 and $50 \$ / \mathrm{MWh}$, which would in effect as much as double the price of electricity ${ }^{6}$ [85]. Note that green certificates for hydrogen are also proposed.

How well can this mechanism work? Can it really induce change, i.e., foster the development of renewables and accelerate it beyond BAU? This is clearly the

\footnotetext{
6 A GC avoids GHG emissions and, therefore, there is a connection between the price of $\mathrm{GC}$ and that of $\mathrm{CO}_{2}$ emission trading rights.
} 
Table 2. $\mathrm{CO}_{2}$ avoidance cost ( $€ /$ tHRC). Source: IEAGHG [42].

\begin{tabular}{lllcc}
\hline & $\begin{array}{l}\text { HRC breakeven } \\
\text { price }\end{array}$ & $\begin{array}{l}\text { Direct } \mathrm{CO}_{2} \\
\text { emission }\end{array}$ & $\begin{array}{l}\% \mathrm{CO}_{2} \\
\text { avoided }\end{array}$ & $\begin{array}{l}\mathrm{CO}_{2} \text { avoidance } \\
\text { cost }\end{array}$ \\
\hline $\begin{array}{l}\text { REFERENCE Steel mill } \\
\begin{array}{l}\text { Steel mill with post-combustion } \\
\text { capture (CASE 2A - EOP-L1) }\end{array}\end{array}$ & 575.23 & $2090.14 \mathrm{~kg} / \mathrm{t} \mathrm{HRC}$ & - & - \\
$\begin{array}{l}\text { Steel mill with post-combustion } \\
\text { capture (CASE 2B - EOP-L2) }\end{array}$ & 652.44 & $1041.73 \mathrm{~kg} / \mathrm{t} \mathrm{HRC}$ & $50.2 \%$ & $\$ 73.64 / \mathrm{t} \mathrm{CO}_{2}$ avoided \\
$\begin{array}{l}\text { Steel mill with OBF \& } \\
\text { MDEA CO } \mathrm{CO}_{2} \text { capture (Case 3) }\end{array}$ & 630.22 & $827.42 \mathrm{~kg} / \mathrm{t} \mathrm{HRC}$ & $60.4 \%$ & $\$ 81.15 / \mathrm{CO}_{2}$ avoided \\
\hline
\end{tabular}

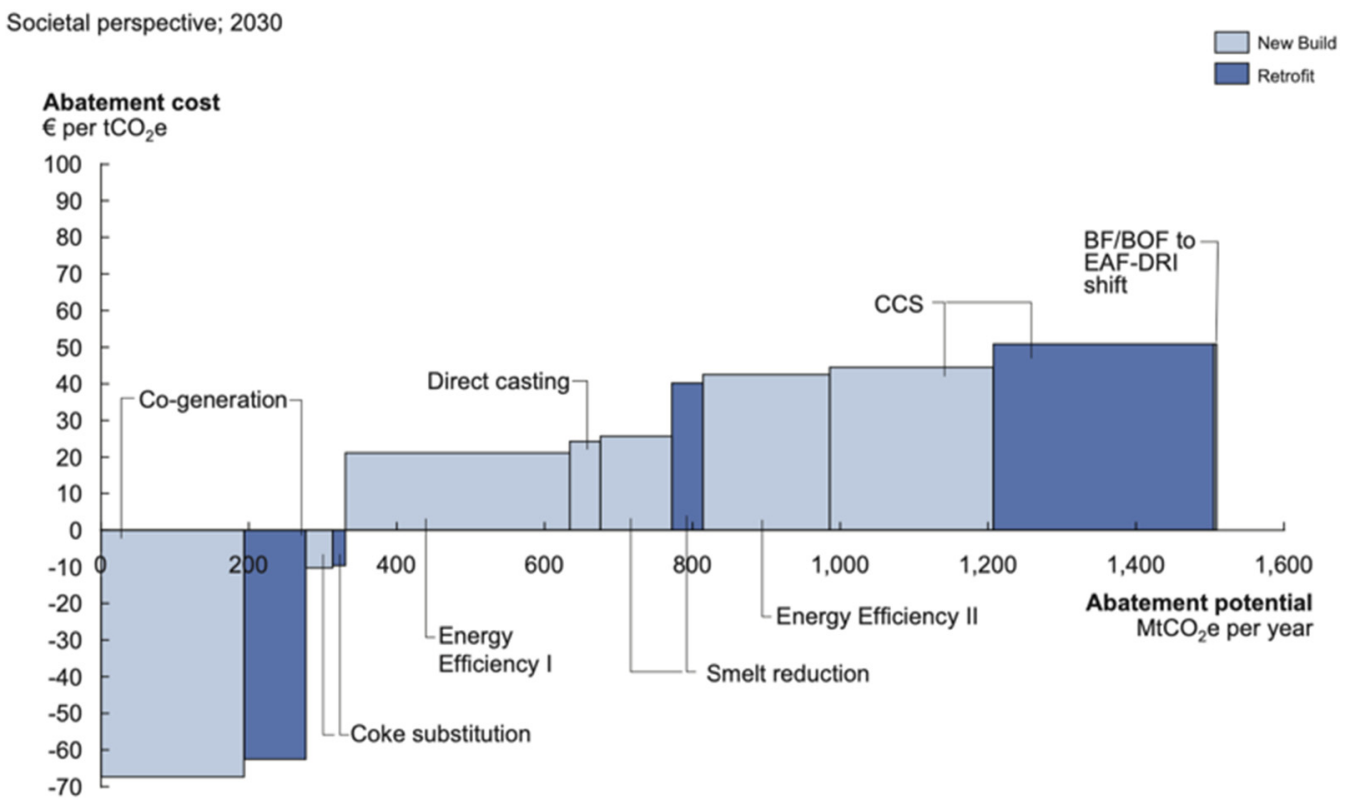

Fig. 18. Global GHG abatement curve for the Iron and Steel sector [38]. Projection for 2030. Source: McKinsey.

objective, but the effectiveness of the instrument still needs to be demonstrated even though GC have been on the table for at least 20 years [86].

There are also ethical issues, due to the fact that the scheme allows for the appropriation of low-carbon power in connection with GC but does not say anything regarding how new power is generated elsewhere to meet demand, especially if it is not willing to pay for green GC: brown energy can replace green energy to meet the overall demand - at least there are no provision in the GC mechanism to alleviate that risk. This difficulty could be handled by a consequential $L C A$ approach, but such studies are not common!

\subsection{Who will pay for hydrogen-based steel production and other zero-carbon production technologies?}

The literature that discusses technology hardly ever tackles costs and the question of how much $\mathrm{H}_{2}$-solutions differ in this area from benchmark steelmaking routes. This information is hidden in the grey literature, outside of the public eye, or in a few papers, either presenting a cost modeling exercise [45] or originating from high-level consultants [41]. See Table 2 and Figure 18, where the numbers are not necessarily comparable (IEAGHG, which was rather transparent, looks only at direct emissions; McKinsey looks at a broader range of process routes, but only at those where the abatement cost (similar to the avoidance cost) is less than $60 € / t_{\mathrm{CO} 2}$; time horizons are different, 2010 and 2030; breakthrough solutions are not included to the same extend as in the present paper, because their avoidance/abatement cost would be higher).

We will not try to extract more intelligible information from these publications, but rather use a rule of thumb estimating the cost of avoidance at $50-100 € / \mathrm{t}_{\mathrm{CO} 2}-$ which is in line with these publications, as a matter of fact.

Complete avoidance, i.e., the zero-carbon target of 2050 , would thus most likely add between 100 and $200 € / t_{\text {steel }}$. 


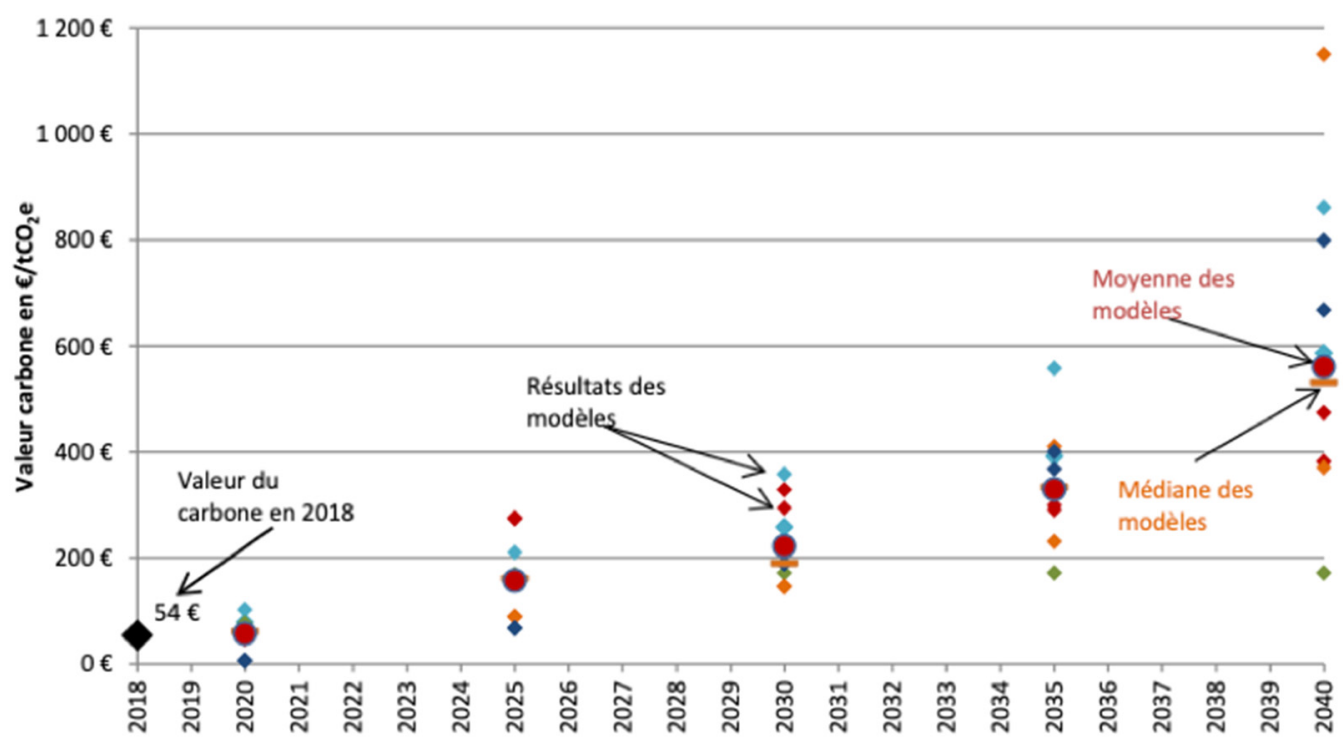

Fig. 19. Carbon values calculated by the various econometric model [87].
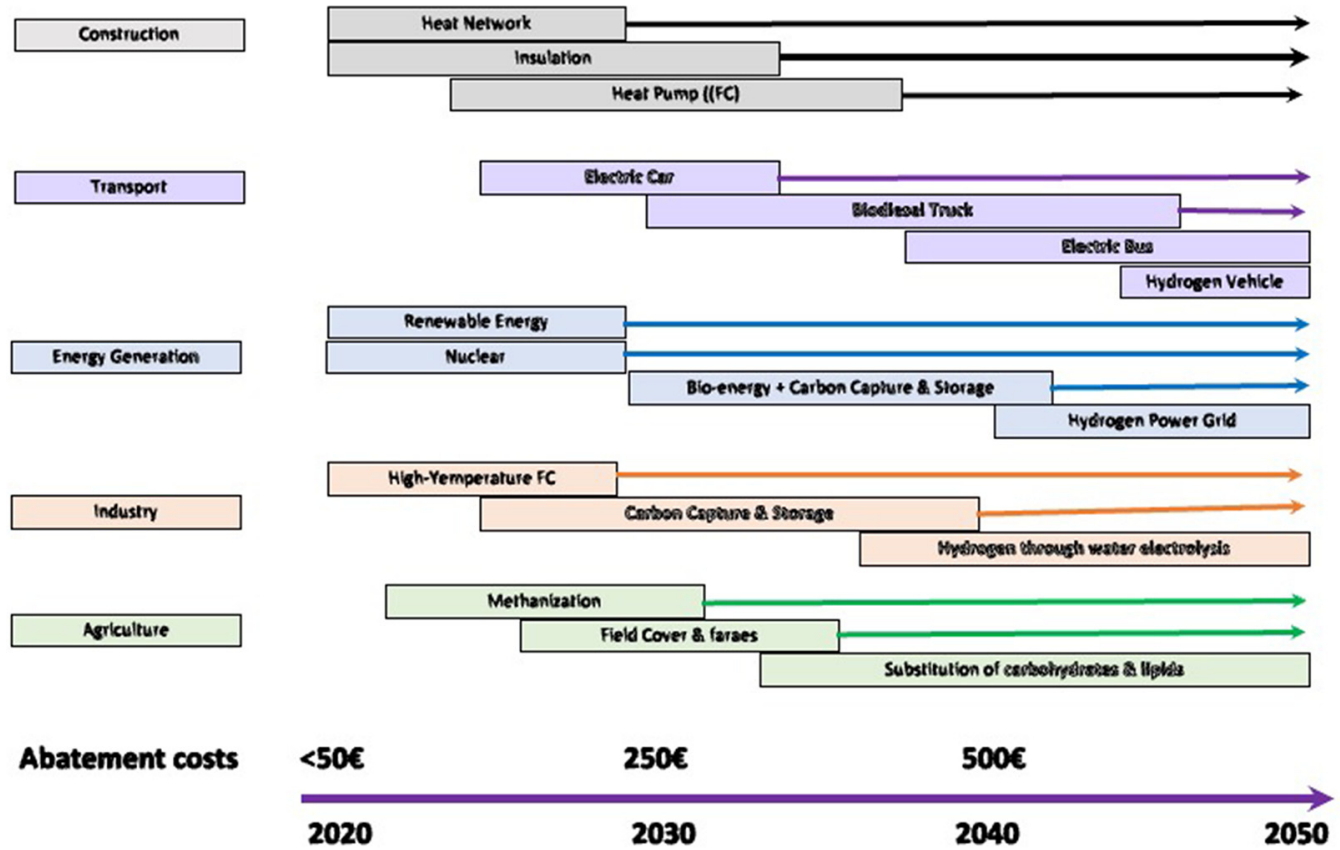

Fig. 20. Cost of deployment of various abatement technologies [87].

\subsection{How reasonable or incongruous is this carbon price?}

We will refer to the document of France Stratégie [87], which estimates what it calls the shadow or normative value of carbon (valeur tutélaire du carbone), i.e., the value of cutting emissions calculated with various econometric models (TIMES, POLES, IMACLIM, ThreeME, NEMESIS) where a thorough, country-wide abatement is taken on board. The rationale is that, if a technology can offer a similar carbon cut at a lower cost than this normative value, then it will be adopted. Figure 19 shows the model estimates and Figure 20 the costs related to various abatement technologies. Readers may remember the Stern Report [88], which proposed a somewhat similar approach in 2007, and the ULCOS paper where carbon value of $400 € / t_{\mathrm{CO} 2}$ were considered as one scenario for the global economy [12]. This work has been expanded and is available in [89,90].

Our rule-of-thumb abatement value, even in its higher bracket, would easily fit below that normative value of carbon.

This discussion also answers our initial question: who will pay for the extra-cost of avoiding carbon emissions? Everyone will, or nobody will, whichever! By 2050 (and probably earlier), the price of carbon will be paid by every player in society, industry, consumers, tax payers, etc. 


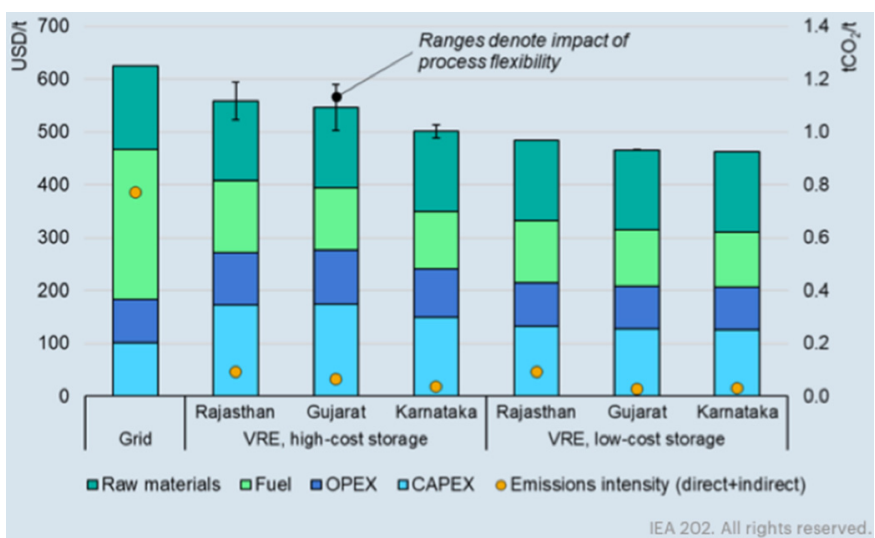

Fig. 21. LCOS produced by hydrogen direct reduction in India, in 2035, ex-VRE [27]. Courtesy of IEA.

Another important likely direction of change is the reduction expected in the price of renewable energy, particularly VRE. Figure 21 shows LCOS projection in India by 2035 , which show a $25 \%$ decline against the grid value [27]. The methodology followed by Armijo and Philibert is explained in [91].

\section{More holistic approaches and considerations}

The Green Deal policy of the European Union has been adopted by all business and industry associations. It does not simply target zero-carbon but also a fully circular economy.

The vision of ArcelorMittal, focused on specific solutions for zero-carbon steel production, is shown in Figure 22 [92]. Its full strategy and agenda for reaching carbon neutrality by 2050 is shown in Figure 23. Some of the process and project names mentioned in Section 4 (IGAR, Blue Hydrogen generation, Green Hydrogen generation, Torero, Carbalyst, CCS, etc.) are articulated in terms of temporality. The company's approach is coherent with its core business of making steel and thus with reducing the specific emissions of its steels. A more recent statement is in [61].

LKAB is a mining company, the largest iron ore miner in Europe [93]. Its focus in the ReeMAP project is on mining waste, which, as a matter of fact, is part of steel's waste from a life cycle or a value-chain perspective [30] (Fig. 24). The project aims at recovering rare earth elements from mining waste, but also phosphorous for fertilizer applications and gypsum: the first minerals are rare and therefore recovering them from waste is clearly part of the circular economy concept.

Another example of a similar trend is Michelin's initiative, whereby the company "is accelerating its drive toward 100 percent sustainability, pledging recently that by 2050 all of its tires will be made entirely from renewable, bio-sourced or otherwise sustainable materials" [94].

Resources are thus stamped as renewable, whether they relate to energy or to materials.
Now, these announcements are part of the storytelling of corporate communication [95]. They relate to Sustainability, an aspirational, kind of moral compass adopted by many society's stakeholders, although, in its "hard" acceptation, it is no more than an oxymoron. There is a continuum between true commitment and green washing. This topic has been handled in the case of plastics in [96], with arguments that can be transposed to steel, mutatis mutandis.

There is also a geopolitical dimension to hydrogen and visions of international trade, either of hydrogen or of ammonia $\mathrm{NH}_{3}$, into which $\mathrm{H}_{2}$ can easily be converted and thus more easily transported: at the end of the pipe or of the sea lane, $\mathrm{NH}_{3}$ can be converted back to $\mathrm{H}_{2}$ or used as such, as it is also an energy carrier with a broad scope of possible applications, including for producing steel $[97,98]$.

The overarching issue is the choice of the energy carrier, of its transport across the world, of the geolocation of GHG emissions and of the appropriation of the rent associated to emissions rights.

Large oil producing regions, like the Middle East, have been shipping oil or gas across the world: producers pocket a fossil fuel rent, while the carbon market creates another rent which is localized in the oil-consuming regions. The idea of transforming oil or gas at the fields into hydrogen, with storage of the resulting $\mathrm{CO}_{2}$ locally or using it as a means for EOR, was proposed in [99]: this would thoroughly redefine GHG emissions in terms of their geographical origin.

Another option would be to process the hydrogen locally and to ship it as iron units (DRI or HBI) across the world: this option is discussed in [100] and the Hybrit project, in Sweden, is proposing a similar concept, although at a practical, operational level-the HBI produced by Hybrit would export REN from Sweden [71].

China, Korea and Japan would be keen to receive hydrogen from abroad-as part of an International Hydrogen supply chain already under organization ${ }^{7}$, cf. Figure 25-as well as DRI [101].

\section{Conclusions}

An explosion of programs related to low-carbon steelmaking has flourished in the last few years. It includes research, but also announcements of investment in new $\mathrm{H}_{2}$-DRI and hydrogen generation plants. The search for Green Steel is on, an echo of the EC's Green Deal policy, driven by every stakeholder in the steel value chain, from customers, shareholders, steel companies themselves and their business organizations.

This is new, given that "green steel" [103] was not emphasized so strongly by many of these stakeholders in the not-so-distant past and that the question of who will pay for the extra-costs incurred by the new technologies, as new investments and extra operating costs, is still unresolved.

\footnotetext{
7 A first green hydrogen shipment of hydrogen was sent from Queensland, Australia, to Japan in March 2019 in a trial experiment. Japan is targeting to introduce $3 \mathrm{Mt} / \mathrm{an}$ of hydrogen by 2030 and $20 \mathrm{Mt} /$ an by 2050, as part of its Green Growth Strategy for 2050 Carbon Neutral, a copycat of the EU Green Deal strategy.
} 


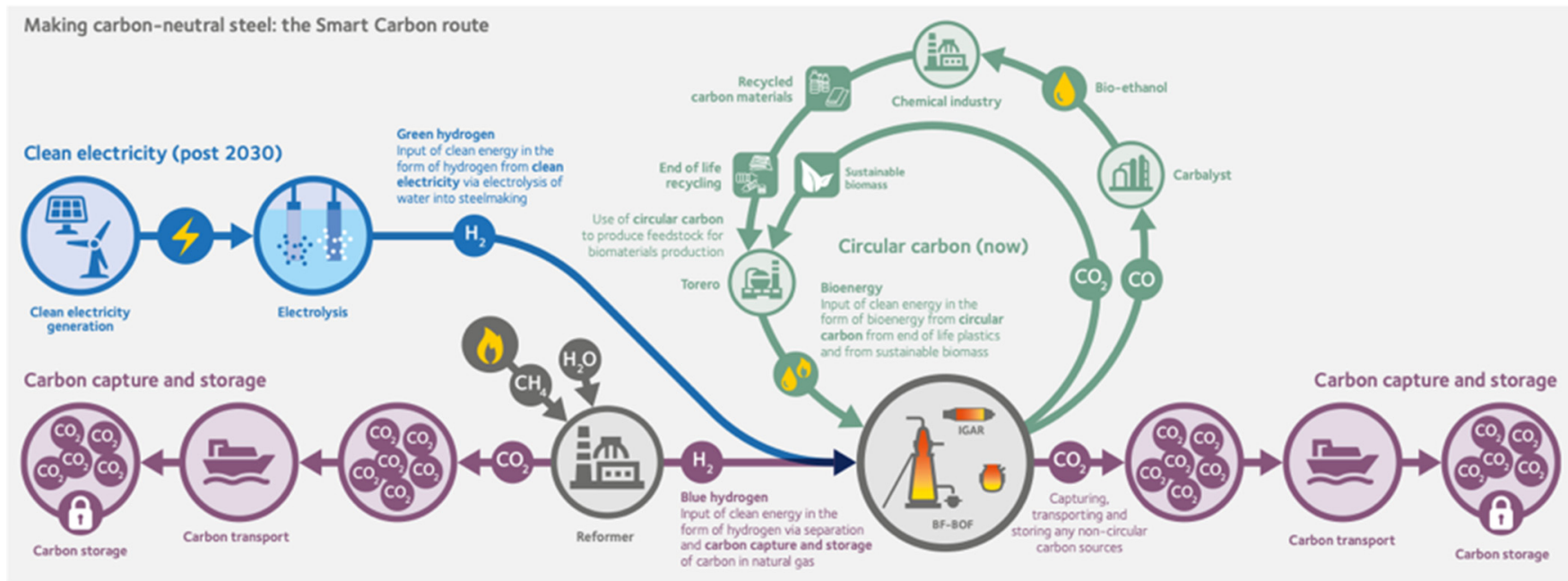

Fig. 22. ArcelorMittal's strategy regarding Climate Change: the "Smart Carbon route" (2020).

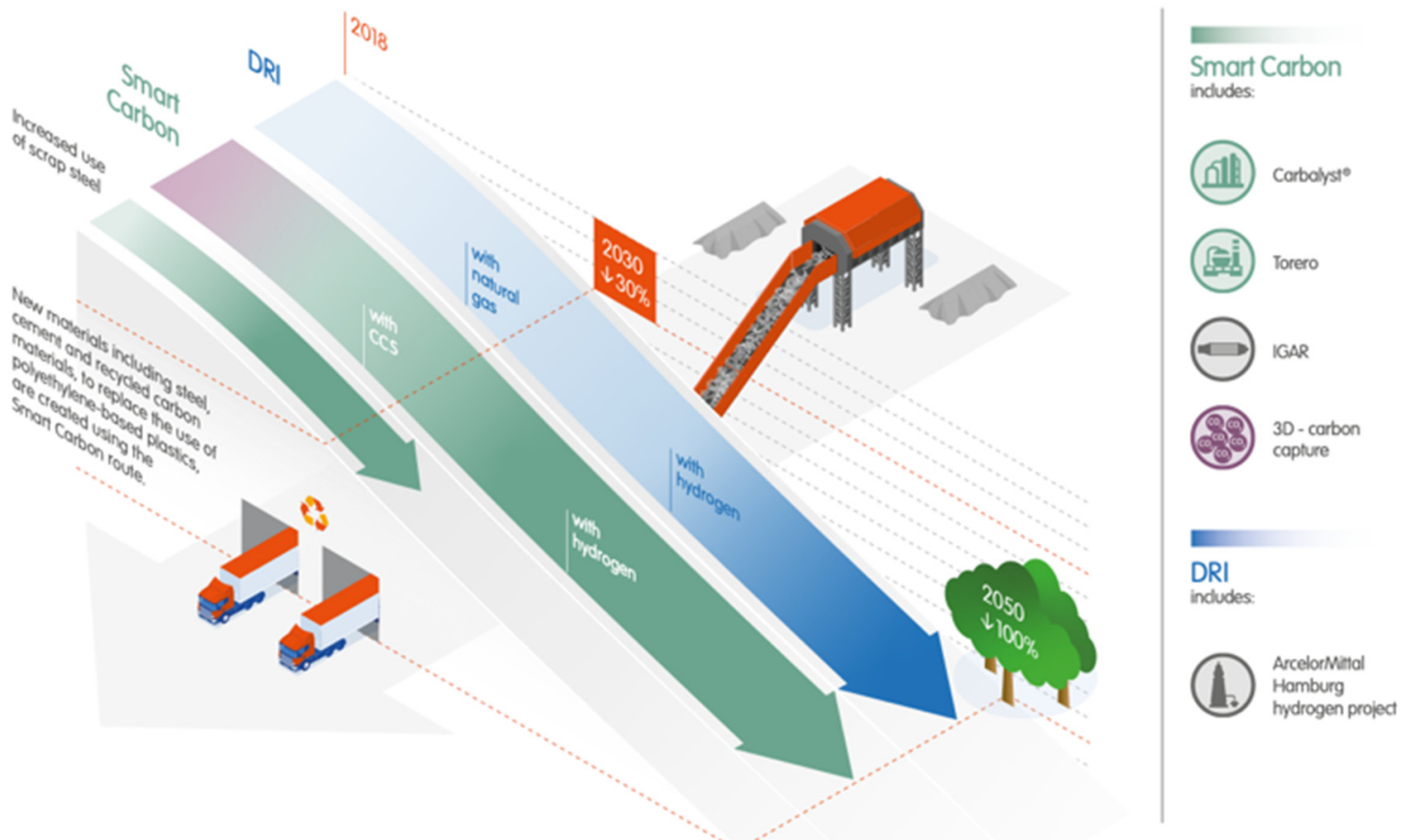

Fig. 23. ArcelorMittal's zero-carbon strategy and agenda (2020).

Listing all ventures, since the historical days in the 1950s when the first pilot experiment of hydrogen direct reduction were run, is fairly easy, except that new items are popping up weekly: the list of projects just passed the 100 mark!

However, this is an account of what happened, not of why it happened!
Engineers and researchers were first given the lead, as there were no simple solutions to cut greenhouse emissions in the steel sector. Indeed, it had already converted into a lean, energy-efficient industry, due to the importance of energy in its conversion costs (25\%). Therefore, only new breakthrough technologies, operating along significant paradigm shifts, could deliver the expected outcome. 


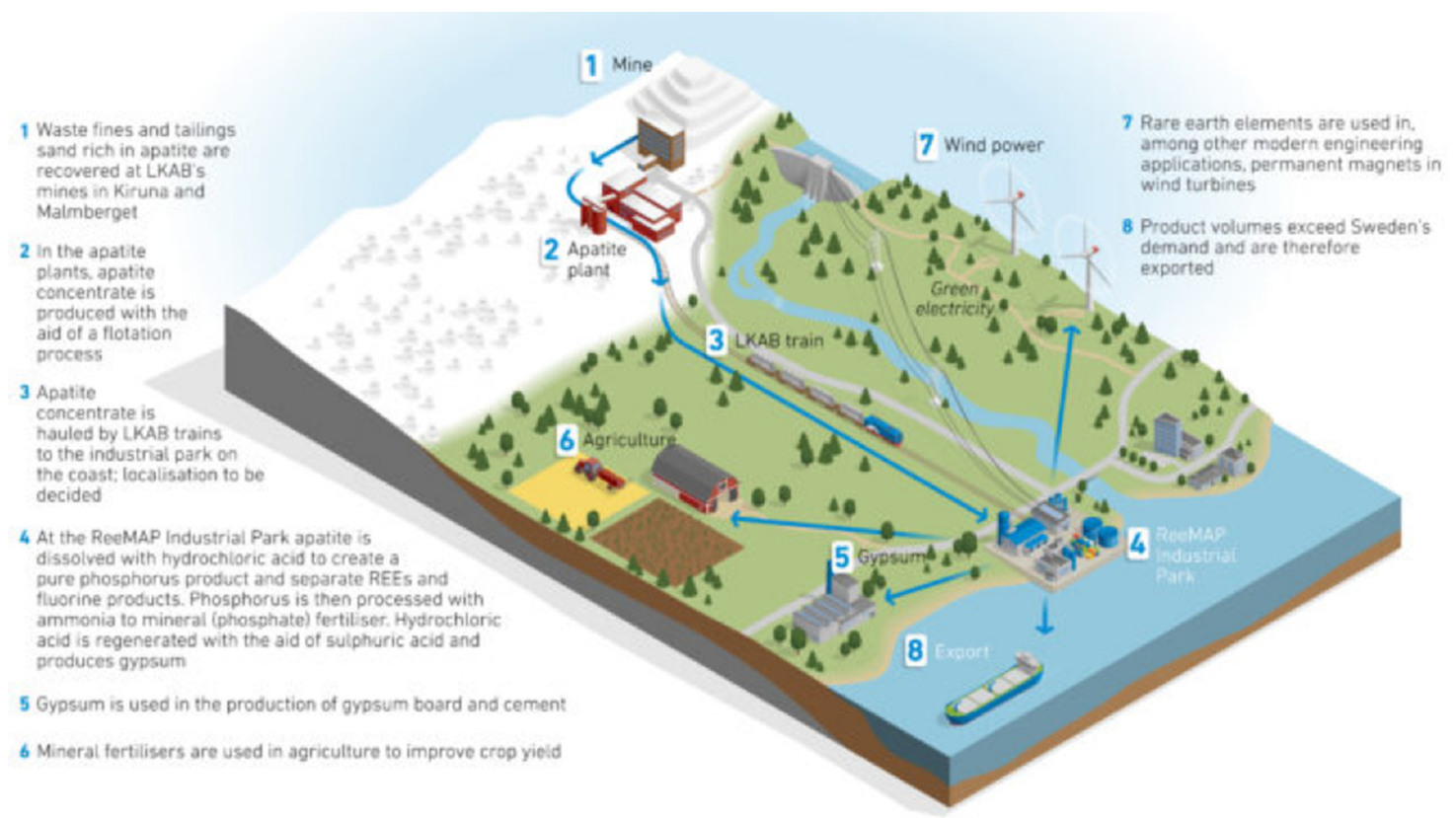

Fig. 24. LKAB's vision for zero-waste mining: the ReeMAP project and the ReeMAP Industrial Park.

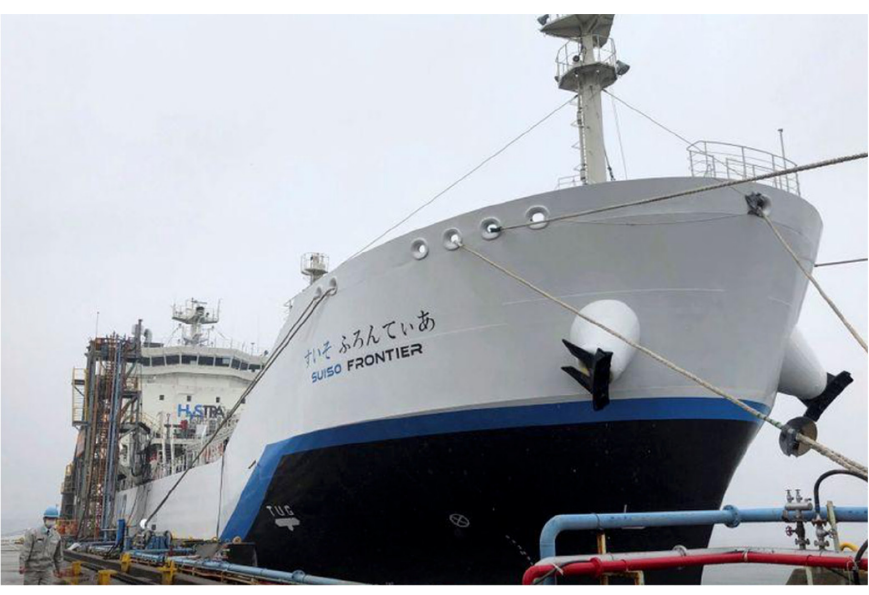

Fig. 25. The Suiso Frontier ${ }^{8}$ transports brown liquid hydrogen from Australia to Japan. Source: Reuters [102].

Solutions to cut emissions from the iron ore route can be organized in terms of capturing carbon emissions for storage or use, thus fossil-fuel based processes (BF, DR, $\mathrm{SR}$ ) with $\mathrm{CCS} / \mathrm{CCU}$, or of substituting carbon as a reducing agent by hydrogen, electricity and possibly other methods. This is similar to the recent presentations of EUROFER which speak of Carbon Direct Avoidance $(C D A)$ and Smart Carbon Use (SCE). An emphasis on using steel scrap (Circular Economy) is also important, although not a strong lever to cut emissions, as steel is fully recovered at end of life (at the level of 85-95\%) and the available amount will grow in the future, but slowly (characteristic time $=$ residence time of steel in the

\footnotetext{
8 水素、すいそ means hydrogen in Japanese.
}

economy, around 40-45 years): in clear wording, it means that scrap recovery should not be allowed to drop below present levels.

Hydrogen, hic et nunc, seems to have a privileged position. Why? The upside and the downside of the concept is that it means getting a series of economic players on board as hydrogen DR means a dichotomy of technologies, thus generating hydrogen (green, pink or blue) and carrying out $\mathrm{H}_{2}$-Direct Reduction. This can generate cooperation and accelerate the emergence of solutions or, on the contrary, create confusion and prevent finding solutions quickly. The future will tell what mechanism will be operating!

One should however note that the steel sector does not put all its eggs in the same basket: work on the $\mathrm{BF}$ with top gas recycling is still on (IGAR, 3D project, TGRBF project at AM-Dunkerque plant with CCS at Equinor's site in the North Sea), smelting reduction from coal is continuing at a large scale at the HIsarna demonstrator and electrolysis of iron ore is well and alive (SIDERWIN, MOE).

Back to the question of paying for breakthrough solutions, the enthusiasm of players in the field and their desire for Green Steel still needs some sinews of war to cover the extra-cost of new solutions. Green certificates, which are akin to emissions rights and add an extra "tax/ value/cost" to the use of hydrogen, may be one solution but the most likely one is a carbon value: at $50-100 € / \mathrm{t}_{\mathrm{CO} 2}$, it would stay below the normative value of carbon. Now who will pay that extra cost? Society as a whole, in all sectors, most probably: however, technology may still be able to cut cost, in the production of hydrogen from RENs and the production of RENs themselves, and in DR technology.

The work and effort reported in this article stems mostly from the STEM community. When investors step in and announce the creation of new plants or mills, this is 
entering the separate of field of business and finance, perhaps economics. However, there is definitely a standpoint missing, that of the SSH community [104].

In the netherworld between STEM and SSH, $L C A$ articles are also lacking: this refers particularly to $\mathrm{H}_{2}$-DR and to the use of consequential LCA to check if solutions indeed will be able to deliver what they claim in terms of GHG emissions reduction. Note that the few papers that deal with the issue seem to point at higher emissions of particulate matter from $\mathrm{H}_{2}$-routes: given the impact of PM on human health, it is a matter that cannot be left unresolved.

Indeed, it constitutes a paradox, akin to the material paradox: whereby all the issues discussed in the paper are meant to alleviate GHG emissions drastically, they may have a deleterious effect on human health and they call on rare and scarce materials.

Another important matter is left unanswered: where should hydrogen be produced? Where should $\mathrm{CO}_{2}$ emissions take place? Where should DR plants be built? Almost all the literature reviewed considers that existing steel mills should be replaced, wherever they are located, by $\mathrm{H}_{2}-\mathrm{DR}$. This is far from obvious and countries like Japan or China envision importing $\mathrm{H}_{2}$ from Australia or the Middle East. This is a much more complex matter than selecting some new piece of technology, as it is of a geopolitical and strategic nature: the present article has hinted at some solutions in Section 8.

\section{List of acronyms}

AP
BAU
BF
BFA
BFB
BFR
CDA
CCS
CCU
CCUS
CIRCORED
CSP
DRA
DR
DRP
EAF
EEA
EGHAC

EHT

ELA

Acidification Potential

Business As Usual

Blast Furnace

BF - Advanced \#1 (pure oxygen + CCS)

BF - Advanced \#2 ( + Biomass $)$

Blast Furnace (+ BOF)

Carbon Direct Avoidance

Carbon Capture and Storage

Carbon Capture and Usage

Carbon Capture, Usage and Storage

name of a directreduction process technology

Clean Steel Partnership

DR Advanced (+CCS)

Direct Reduction

Direct Reduction

Electric Arc Furnace

European Environment Agency

European Green Hydrogen Acceleration Center (flagship project of the EIT InnoEnergy)

Electrolysis at High Temperature (Electrolysis)

ELB Electrolysis Alkaline, ULCOWIN (electrical grid mix)

ENERGIRON name of a direct reduction process technology, formerly known as Hylsa
EOR

EPR

EU

FIT

FOAK

GC

$G E S$

GWP

$\mathrm{H}_{2}$-DRI-HBI

H-IRON

HEU

HIsarna

HYBRIT

HYLSA

IM

IPCEI

LCA

$\mathrm{LCOS}$

$\mathrm{LCOE}$

$\mathrm{LCOH}$

LKAB

MFA

MIDREX

NER

OFWT

ReeMAP

REC

REN

RFCS

SCE

SIDERWIN

SMR

$\mathrm{SR}$

SRP

$\mathrm{SSH}$

STEM

TGRBF

TRL

ULCOS

ULCOWIN
Enhanced Oil Recovery

Evolutionary Reactor, formerly: European Pressurized Reactor

European Union

(novel) Flash Ironmaking Technology

First Of A Kind (industrial plant, sometimes called TRL 11)

Green Certificate

gaz à effet de serre

Global Warming Potential

Direct Reduced Iron \& Hot Bricketed Iron, produced from hydrogen

name of a direct reduction process technology experimented in the $1950 \mathrm{~s}$

Horizon Europe, R\&I Framework program

name of a smelting reduction process technology

HYdrogen BReakthrough Ironmaking Technology, name of a direct reduction process technology

a Mexican Steel Company, which developed a direct reduction technology and gave it its name

Integrated Mill

Important Project of Common European Interest

Life-Cycle Assessment

Levelized Cost of Steel

Levelized Cost of Electricity

Levelized Cost of Hydrogen

Luossavaara-Kiirunavaara Aktiebolag, name of a Swedish mining company

Material Flow Analysis

name of a direct reduction process technology

New Entrants' Reserve, name of financing instruments proposed by the European Commission for financing low-carbon endeavors

OFfshore Wind Turbines

Rare Earth Elements and Mono-Ammonium Phosphate, Swedish project carried by $L K A B$

Renewable Energy Certificates

Renewable ENergy

Research Fund for Coal and Steel

Smart Carbon Use

Development of new methodologieS for InDustrial $\mathrm{CO}_{2}$-freE steel pRoduction by electroWINning

Steam Methane Reforming

Smelting Reduction

Smelting Reduction Process

Social Sciences and Humanities

Science, Technology, Engineering, Mathematics

Top-Gas-Recycling Blast Furnace

Technology Readiness Level

ULtra-low- $\mathrm{CO}_{2}$ Steelmaking

ULCOs electroWINning 
VRE

Variable Renewable Energy

\section{Appendix A: Comparison between the "ULCOS solutions"}

Below, we present a clearer analysis of the various "ULCOS solutions" (cf. their definition in [3]), which, however, did not include a hydrogen DR route.
Where energy is concerned (Fig. A1), 15 to 25\% improvement is brought about by all routes, with NG direct reduction and electrolysis performing at the best level.

In terms of GHG emissions, all solutions perform better than the benchmark, cf. Figure A2.

In terms of operating costs, all solutions are regret solutions, except for HIsarna, which did not exist at the time when these simulations were run-thus not quite a true regret solution as a new technology had still to be developed at the time (Fig. A3). Since time would need to

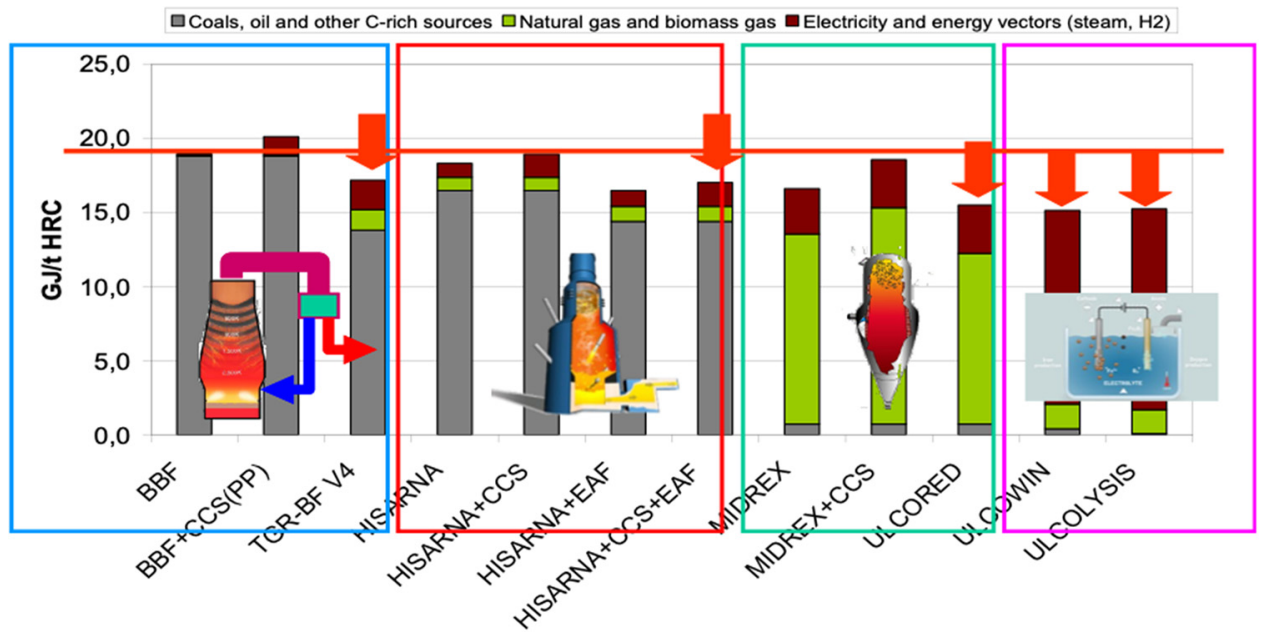

Fig. A1. Energy needs of the ULCOS Solutions $\left(\mathrm{GJ} / \mathrm{t}_{\mathrm{HRC}}\right)$.

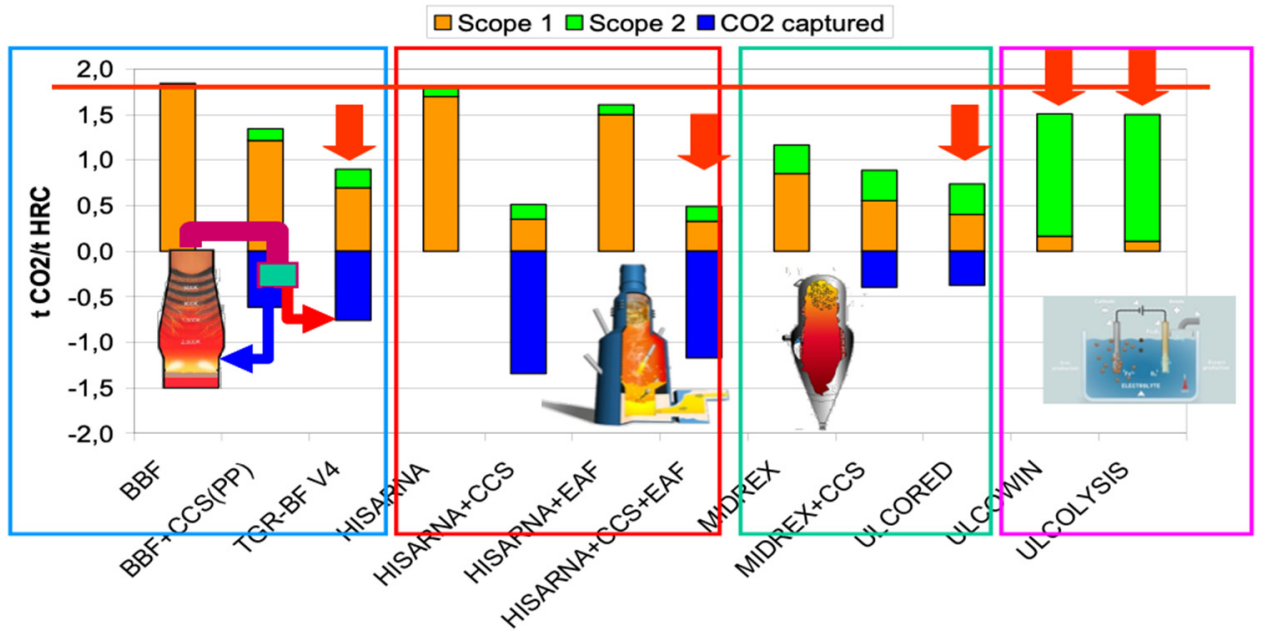

Fig. A2. $\mathrm{CO}_{2}$ emissions per ton of Hot Rolled Coil (HTC) of the ULCOS Solutions. 


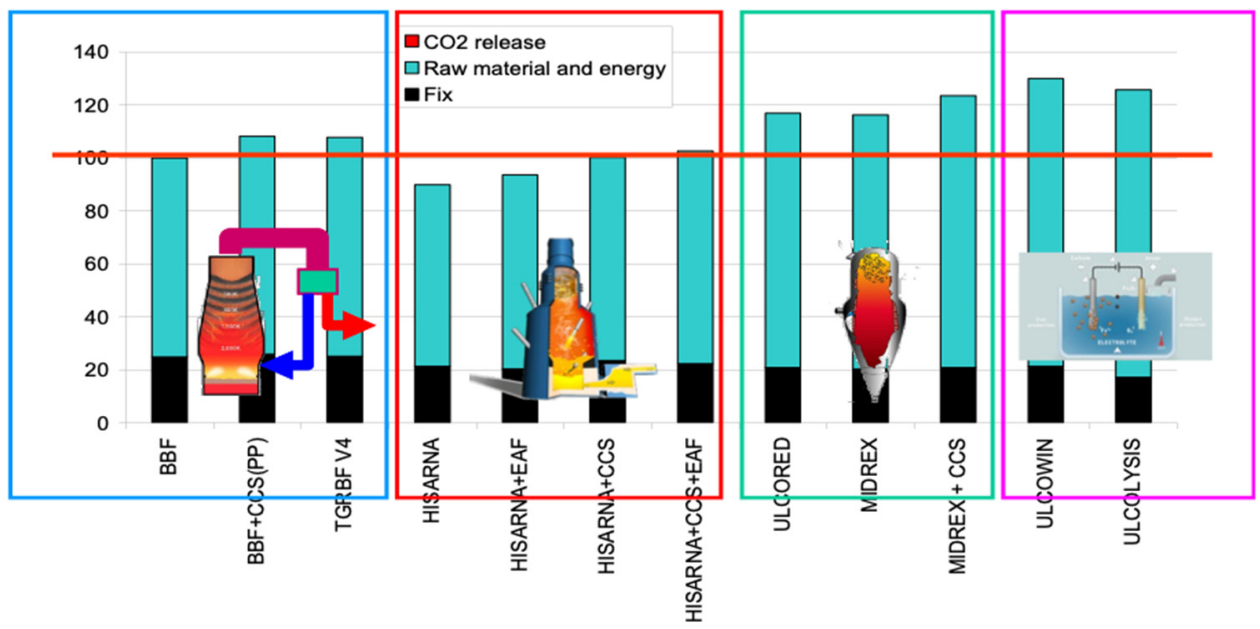

Fig. A3. Operating costs in 2010 of the ULCOS Solutions (index).

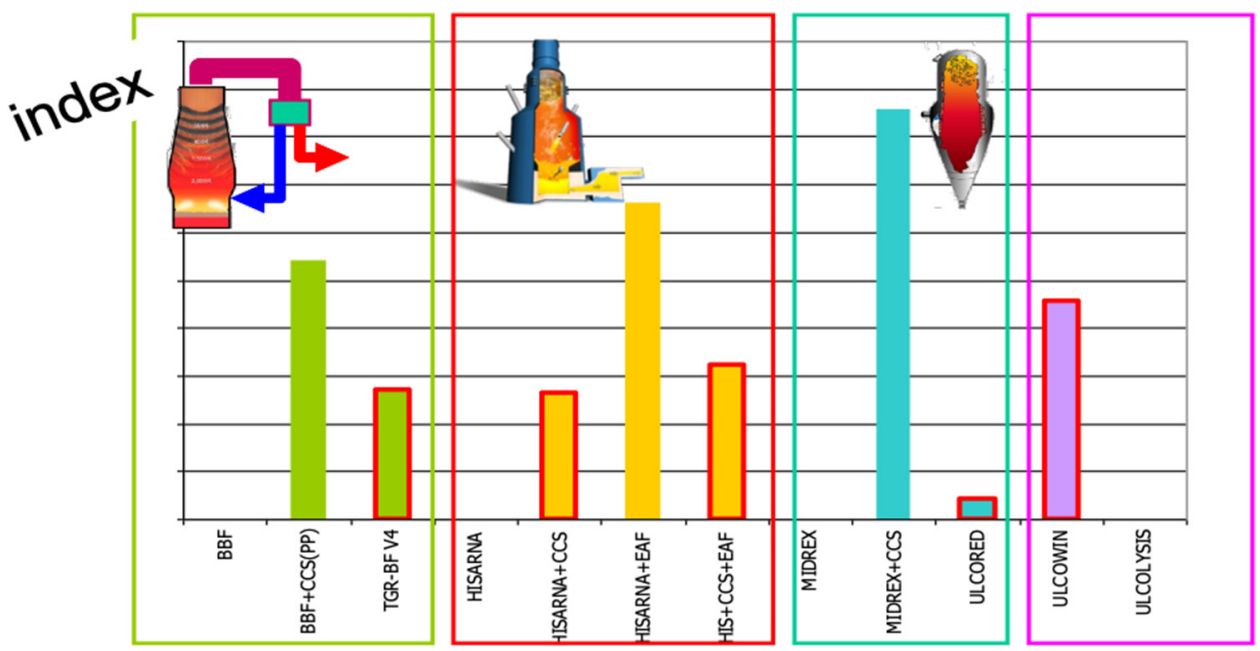

Fig. A4. Cost of avoided $\mathrm{CO}_{2}$ of the ULCOS Solutions.

be factored in the economic modeling to take this point on board, the conclusions of Figure A4 would have to be followed.

\section{References}

1. J.-P. Birat, M. Antoine, A. Dubs, et al., Vers une sidérurgie sans carbone?, in: Journées sidérurgiques 1992, 16 au 17 décembre, 1992 ; Revue de métallurgie 90, 411 (1993)

2. CIRCORED Hydrogen-based reduction, METSO-OTTOTEC, https://www.mogroup.com/portfolio/circored-hydro gen-based-reduction

3. J.-P. Birat, J. Borlée, B. Korthas, et al., ULCOS program: A progress report in the spring of 2008, in: Scanmet III, 3rd International Conference on Process Development in Iron and Steelmaking, 8-11 June, 2008, Luleå, Sweden

4. J.-P. Birat, $\mathrm{CO}_{2}$-lean steelmaking: ULCOS, other international programs and emerging concepts, in: ECCR Steel (METEC-2011), 2011
5. J.-P. Birat, The progress and status of IISI's $\mathrm{CO}_{2}$ Breakthrough Program and EU's ULCOS, in: $\mathrm{CO}_{2}$ Reduction Workshop, 1-2 November, Kaohsiung, Taiwan, 2007

6. Breaking through the technology barriers: Steel producers are researching new production technologies that would radically reduce their environmental footprint, Fact SheetBreakthrough technologies, worldsteel pamphlet, 2008

7. World steel in figures, Worldsteel, 2020

8. J.-P. Birat, Chapter 2: Materials, greenhouse gas emissions and climate change, in: Sustainable Materials ScienceEnvironmental Metallurgy, Volume 2: Materials: Pollution and emissions, biodiversity, toxicology and ecotoxicology, economics and social roles, foresight, EDP Science, 2021, pp. $43-120$

9. D. Morin, Biotechnologies dans la métallurgie extractiveMicrobiologie et extraction des métaux, Technique de l'Ingénieur, (2020), M2238 v4

10. J.-P. Birat, J.P. Lorrain, Y. de Lassat, The " $\mathrm{CO}_{2}$ tool": $\mathrm{CO}_{2}$ emissions and energy consumption of existing and breakthrough steelmaking routes, La Revue de Métallurgie-CIT, 325-336 (2009)

11. J.-P. Birat, J.P. Lorrain, Y. de Lassat, The "cost tool", La Revue de Métallurgie-CIT, 337-349 (2009) 
12. E. Bellevrat, Ph. Menanteau, Introducing carbon constraint in the steel sector: ULCOS scenarios and economic modeling, La Revue de Métallurgie-CIT, 318-324 (2009)

13. J.-P. Birat, Carbon dioxide $\left(\mathrm{CO}_{2}\right)$ capture and storage technology in the iron and steel industry, in: M.M. MarotoValer (ed.), Developments \& innovation in carbon dioxide $\left(\mathrm{CO}_{2}\right)$ capture and storage technology, Volume 1: Carbon dioxide $\left(\mathrm{CO}_{2}\right)$ capture, transport and industrial applications, Woodhead Publishing, 2010, pp. 493-521

14. J.-P. Birat, The future of $\mathrm{CO}_{2}$-lean steelmaking - Technology developments towards 2050, in: Scenario 2050 for the Iron \& Steel industry in Northern Europe, Luleå, 2011

15. J.-P. Birat, Hydrogen and steel, in: Seminar organized by FCH-JU, Bruxelles, 22 March, 2012

16. J.-P. Birat, F. Hanrot, G. Danloy, $\mathrm{CO}_{2}$ mitigation technologies in the steel industry: A benchmarking study based on process calculations, Stahl und Eisen 123(9), 69$72(2003)$

17. K. Meijer, M. Denys, J. Lasar, et al., ULCOS: Ultra-Low $\mathrm{CO}_{2}$ Steelmaking, Ironmak. Steelmak. Process. Prod. Appl. 36(4), 249-251 (2009), https://doi.org/10.1179/ $174328109 \times 439298$

18. J.-P. Birat, Steel Sectoral Report, Contribution to the UNIDO roadmap on CCS, in: "Global Technology Roadmap for CCS in Industry" sectoral workshop, Abu Dhabi, 30 June-1 July, 2010, Available from https://www.global ccsinstitute.com/archive/hub/publications/15671/globaltechnology-roadmap-ccs-industry-steel-sectoral-report.pdf

19. J. Borlée, Low $\mathrm{CO}_{2}$ Steels - ULCOS Project (Ultra-Low $\mathrm{CO}_{2}$ Steelmaking), in: Proceedings of the IEA Deployment Workshop, 8-9 October 2007, Paris, France, 2007

20. J. van der Stel, M. Hattink, C. Zeilstra, et al., ULCOS top gas recycling blast furnace process (ULCOS TGRBF), European Commission report EUR 26414 EN, Research and Innovation, 2014, $53 \mathrm{p}$

21. F. Patisson, O. Mirgaux, Hydrogen ironmaking: How it works?, Metals (2020), https://doi.org/10.3390/ met10070922

22. A. Allanore, H. Lavelaine, G. Valentin, J.-P. Birat, F. Lapicque, Iron metal production by bulk electrolysis of iron ore particles in aqueous media, J. Electrochem. Soc. 155(9) E125-E129 (2008)

23. A. Allanore, H. Lavelaine, G. Valentin, et al., Observation and modelling of the reduction of hematite particles to metal in alkaline solution by electrolysis, Electrochim. Acta 55, 4007-4013 (2010)

24. A. Allanore, H. Lavelaine, J.-P. Birat, et al., Experimental investigation of cell design for the electrolysis of iron oxide suspensions in alkaline electrolyte, J. Appl. Electrochem., (2010)

25. H. Lavelaine, et al., Iron production by electrochemical reduction of its oxide for high $\mathrm{CO}_{2}$ mitigation (IERO), RFCS Final report, EUR 28065 EN, 2016

26. H. Lavelaine, $\Sigma$ IDERWIN partners, $\Sigma$ IDERWIN project: Electrification of primary steel production for direct $\mathrm{CO}_{2}$ emission avoidance, in: METEC/ESTAD, 24-28 June, 2019, Düsseldorf, Germany, https://www.siderwin-spire.eu/ sites/siderwin.drupal.pulsartecnalia.com/files/documents/ SIDERWIN_project_estad2019.pdf

27. Iron and Steel Technology Roadmap-Towards more sustainable steelmaking, IEA, 2020
28. J.W.K van Boggelen, H.K.A Meijer, C. Zeilstra, H. Hage, P. Broersen, HIsarna-Demonstrating low $\mathrm{CO}_{2}$ ironmaking at pilot scale, in: Steel VIA, 25-27 September, 2018, Dubai

29. K. Meijer, C. Zeilstra, H. Hage, P Broersen, J. van Boggelen, Various roads to $\mathrm{CO}_{2}$ reduction with HIsarna technology, In: METEC/ESTAD, 24-28 June, 2019, Düsseldorf, Germany

30. J.-P. Birat, Society, materials and the environment: The case of Steel, Metals 10(331), 36 (2020), https://doi.org/ 10.3390/met10030331

31. Y. Junjie, Progress and future of breakthrough low-carbon steelmaking technology (ULCOS) of EU, Int. J. Miner. Process. Extract. Metall. 3(2), 15-22 (2018), https://doi. org/10.11648/j.ijmpem.20180302.11

32. M. Abdul Quadera, A. Shamsuddin, S.Z. Dawal, Y. Nukman, Present needs, recent progress and future trends of energy-efficient Ultra-Low Carbon Dioxide $\left(\mathrm{CO}_{2}\right)$ Steelmaking (ULCOS) Program, Renew. Sustain. Energy Rev. 55, 537-549 (2016)

33. A. Toktarova, I. Karlsson, J. Rootzén, et al., Pathways for low-carbon transition of the steel industry - A Swedish case study, Energies 13, 3840 (2020), https://doi.org/10.3390/ en13153840

34. L. Holappa, A general vision for reduction of energy consumption and $\mathrm{CO}_{2}$ emissions from the steel industry, Metals 10, 1117 (2020), https://doi.org/10.3390/ met10091117

35. S. Jahanshahi, J.G. Mathieson, H Reimink, Low emission steelmaking, J. Sustain. Metall. 2, 185-190 (2016), https:// doi.org/10.1007/s40831-016-0065-5

36. M.C. Romanoa, R. Anantharamanb, A. Arastoc, et al., Application of advanced technologies for $\mathrm{CO}_{2}$ capture from industrial sources, GHGT-11, Energy Procedia 37, 71767185 (2013)

37. J. Tang, M.-S. Chu, F. Li, et al., Development and progress of hydrogen metallurgy, Int. J. Miner. Metall. Mater. 27(6), 713 (2020), https://doi.org/10.1007/s12613-020-2021-4

38. M. Weigel, M. Fischedick, J. Marzinkowski, et al., Multicriteria analysis of primary steelmaking technologies, J. Clean. Prod. 112, 1064e1076 (2016)

39. M. Fischedick, J. Marzinkowski, P. Winzer, et al., Technoeconomic evaluation of innovative steel production technologies, J. Clean. Prod. 84, 563e580 (2014)

40. N. Alazard-Thoux, et al., (including J.-P. Birat), Decarbonization wedges, Report, 2015, ANCRE (France), $56 \mathrm{p}$ (document prepared for the COP21 Meeting).

41. Pathways to a low-carbon economy - Version 2 of the Global Greenhouse Gas Abatement curve, McKinsey, 2009, 190 p, https://www.mckinsey.com/ /media/mckinsey/dotcom/ client_service/sustainability/cost $\% 20$ curve $\% 20$ pdfs/path ways_lowcarbon_economy_version2.ashx

42. C. Hoffmann, M. Van Hoey, B. Zeumer, Decarbonization challenge for steel-Hydrogen as a solution in Europe, McKinsey, 2020, 11 p (pamphlet, executive summary)

43. F. Schuler, N. Voigt, T. Schmidt, et al., Steel's contribution to a low-carbon Europe 2050: Technical and economic analysis of the sector's $\mathrm{CO}_{2}$ abatement potential, 2013, BCG and EUROFER, $45 \mathrm{p}$, https://www.stahl-online.de/wpcontent/uploads/2013/09/Schlussbericht-Studie-Low-car bon-Europe-2050_-Mai-20131.pdf

44. N. Pardo, J.A. Moya, K. Vatopoulos, Prospective scenarios on energy efficiency and $\mathrm{CO}_{2}$ emissions in the EU Iron \& Steel Industry-Re-edition, 2012, Joint Research Center, JRC74811, EUR 25543 EN 
45. Understanding the techno-economics of deploying $\mathrm{CO}_{2}$ capture technologies in an integrated steel mill, in: Iron and Steel CCS Study-Techno-Economic Integrated Steel Mill, 4 July 2013, IEAGHG, 2013

46. D. Leesonl, J. Fairclough, C. Petit, P. Fennell, A systematic review of current technology and cost for industrial carbon capture, Imperial College, Granhtam Institute, Report GR7, 2014, 81 p, https://www.imperial.ac.uk/media/imperial-col lege/grantham-institute/public/publications/institutereports-and-analytical-notes/A-Systematic-Review-of-In dustrial-CCS-GR7.pdf

47. M.T. Ho, A. Bustamante, D.E. Wiley, Comparison of $\mathrm{CO}_{2}$ capture economics for iron and steel mills, Int. J. Greenhouse Gas Control, 27 (2013)

48. B.J. Macmullan, Le procédé "H-Iron", Rev. Met. Paris 61(7-8), 635-638 (1964)

49. Finance for installations of innovative renewable energy technology and CCS in the EU, http://www.ner300.com

50. https://ec.europa.eu/clima/policies/innovation-fund_en

51. Global climate roadmap: Reducing our emissions \& growing our supplies to the green transition, 2021, ELKEM document

52. Steel's contribution to a low carbon future, worldsteel position paper, 2013, https://www.worldsteel.org/en/dam/ jcr:11b74b34-1709-4680-bcf8-0c7044d9e0b9/Steel\%2527s

+ Contribution + to + a + Low + Carbon + Future + .pdf

53. COURSE 50 Program, https://www.course50.com/en/

54. SIDERWIN, https://www.siderwin-spire.eu

55. Boston Metal, https://www.bostonmetal.com/home/

56. Projet VALORCO, VALORisation et Réduction des émissions de $\mathrm{CO}_{2}$ en Industrie, ADEME, https://www. ademe.fr/sites/default/files/assets/documents/valorco.pdf

57. Projet IGAR, ADEME, https://ibrairie.ademe.fr/ recherche-et-innovation/1123-igar.html

58. Primary Energy Melter, SMS, https://www.sms-group.com/ plants/all-plants/converter-steelmaking-carbon-steel/pem-pri mary-energy-melter

59. C4U project, https://c4u-project.eu

60. Oxygen blast furnace of China's steel mill achieves $35 \%$ enriched-oxygen smelting, Pioneer, China, online on 202101-14, http://www.chinamet.cn/Jweb_gtyjxb_cn/EN/ab stract/abstract142258.shtml

61. Climate Action Report 2, 2021, ArcelorMittal document

62. Elkem to test the world's first carbon capture pilot for smelters, ELKEM website, 2021, https://www.elkem.com/ media/news/article/?itemid =8F34AF42688D0767

63. Production et consommation d'hydrogène aujourd'hui, Memento de l'hydrogène, AFHYPAC, Fiche 1.3, 2016, and 2019 data

64. J.-P. Birat, Decarbonising steel-An international perspective, in: IEA-CNREC, Renewable Energy for Industry and Fuels Workshop, 可再生能源在工业和燃料中的应用国际研 讨会, 22-23 January, 2019, Beijing

65. N.M.A. Huijts, C.J.H. Midden, A.L. Meijnders, Social acceptance of carbon dioxide storage, Energy Policy 35, 2780-2789 (2007)

66. R. Bhandari, C.A. Trudewind, P. Zap, Life cycle assessment of hydrogen production methods - A review, STE Research Report, Jülich Froschungszentrum, 2012
67. A. Simons, C. Bauer, Chapter 2: Life cycle assessment of hydrogen production (pp. 13-57), in: A. Wokaun, E. Wilhelm (eds.), Transition to Hydrogen, Cambridge University Press, 2011, https://doi.org/10.1017/ CBO9781139018036.006

68. T. Wichl, W. Lueke, G. Deerber, et al., Carbon2Chem@CCU as a step toward a circular economy, Front. Energy Res., (2020), https://doi.org/10.3389/fenrg.2019.00162

69. MIDREX NG, MIDREX, https://www.midrex.com/tech nology/midrex-process/midrex-ng/

70. ENERGIRON Direct Reduction processes, Tenova \& Danieli, https://www.energiron.com

71. HYBRIT on LKAB's websites, https://www.ssab.fr/prod ucts/brands/greencoat/sustainable-building-with-green coat/hybrit-fossil-free-steel, https://www.lkab.com/en/ about-lkab/technological-and-process-development/re search-collaborations/hybrit-for-fossil-free-steel/

72. HYBRIT on SSAB's website, https://www.ssab.com/com pany/sustainability/sustainable-operations/hybrit

73. HYBRIT on Vattenfall's website, https://www.vattenfall. $\mathrm{fr} /$ le-mag-energie/hybrit-production-acier-decarbone

74. J.-P. Birat, P. Criqui, Article «Décarbonation de la sidérurgie», in: Dictionnaire historique de la sidérurgie, Édition de Provence (To be published in 2022)

75. Green Steel for Europe-A project run by ESTEP, Bruxelles, https://www.estep.eu/green-steel-for-europe/

76. Que faut-il retenir de l'ordonnance sur l'hydrogène? 18/02/ 2021, AFHYPAC, https://www.afhypac.org/presse/quefaut-il-retenir-de-l-ordonnance-sur-l-hydrogene-2953/

77. Modes de production du dihydrogène, CEA, découvrir et comprendre, https://www.cea.fr/comprendre/Pages/ener gies $/$ renouvelables $/$ hydrogene.aspx?Type=Chapitre\&nu mero $=3$

78. I. Moretti, L'hydrogène naturel: curiosité géologique ou source d'énergie majeure dans le futur? CDE, Connaissance des énergies, 22 mai 2020, https://www.connaissancedese nergies.org/tribune-actualite-energies/lhydrogene-naturelcuriosite-geologique-ou-source-denergie-majeure-dans-lefutur

79. Bringing fusion to the US grid, US National Academies, 2021, https://www.nap.edu/read/25991/chapter/1

80. SPARC Project, MIT, https://news.mit.edu/2020/physicsfusion-studies-0929

81. Electricity Map, https://www.electricitymap.org/map

82. European Environment Agency, Greenhouse gas emission intensity of electricity generation, https://www.eea.euro pa.eu/data-and-maps/daviz/co2-emission-intensity6\#tab-googlechartid_googlechartid_googlechartid_goo glechartid_chart_11111

83. S. Huet, Électricité et $\mathrm{CO}_{2}$ - le tableau européen, Le Monde, (2019), https://www.lemonde.fr/blog/huet/2019/05/06/ electricite-et-co2-le-tableau-europeen/

84. B. Paolo, H. Thomas, Tradable certificates for renewable electricity and energy savings, Energy Policy 34, 212-222 (2005)

85. X. Yu, Z. Dong, D. Zhoua, et al., Integration of tradable green certificates trading and carbon emissions trading: How will Chinese power industry do? J. Clean. Prod. 279, (2021)

86. J. Canton, A. Johannesson Lindén, Support schemes for renewable electricity in the EU, Economic Papers 408, (2010), KC-AI-10-408-EN-N, http://ec.europa.eu/econo my_finance/publications/economic/index_en.htm 
87. A. Quinet (Rapport de la commission présidée par), La valeur de l'action pour le climat-Une valeur tutélaire du carbone pour évaluer les investissements et les politiques publiques, France Stratégie, 2019

88. N.H. Stern, The economics of climate change: The Stern review, Cambridge University Press, Cambridge, UK, 2007

89. P. Criqui (Président), S. Crémel, A. Pommeret (Rapporteurs), Les coûts d'abattement, Partie 1, Méthodologie, France Stratégie, 2021, 66 p, https://www.strategie.gouv. $\mathrm{fr} /$ publications/couts-dabattement

90. P. Criqui (Président), S. Crémel, A. Pommeret (Rapporteurs), Les coûts d'abattement, Partie 2, Transport, France Stratégie, 2021, 66 p, https://www.strategie.gouv.fr/publi cations/couts-dabattement

91. J. Armijo, C. Philibert, Flexible production of green hydrogen and ammonia from variable solar and wind energy. Case study of Chile and Argentina, Int. J. Hydrogen Energy, (2019)

92. Climate Action in Europe, Our carbon emissions reduction roadmap: $30 \%$ by 2030 and carbon neutral by 2050, ArcelorMittal, 2020, https://corporate-media.arcelormit tal.com/media/yw1gnzfo/climate-action-in-europe.pdf

93. LKAB: Today's waste becomes tomorrow's resources, The ReeMAP Project, https://ree-map.com/about-reemap/ree map-industrial-park/

94. Stratégie Michelin, https://www.rubbernews.com/sustain ability/video-michelin-driving-100-sustainable-tires-2050

95. J.-P. Birat, Quelle place pour l'acier et la sidérurgie dans les sociétés post-modernes, etc...? Récits et storytelling, in: Journée scientifique et amicale en l'honneur de Denis Ablitzer, 3 septembre, 2014, École des Mines de Nancy, Nancy
96. A. Mah, Future-proofing capitalism: The paradox of the circular economy for plastics, Glob. Environ. Politics 21(2), (2021), https://doi.org/10.1162/glep_a_00594

97. S. Hosokai, Y. Kasiwaya, K. Matsui, et al., Ironmaking with ammonia at low temperature, Environ. Sci. Technol. 45, 821-826 (2011)

98. N. Yasuda, Y. Mochizuki, N. Tsubouchi, et al., Reduction and nitriding behavior of hematite with ammonia, ISIJ Int. 55(4), 736-741 (2015)

99. J.-P. Birat, A. Carvallo Aceves, Territorial sustainability footprint, Revue de Métallurgie 109, 323-331 (2012)

100. D. Gielen, D. Saygin, E. Taibi, J.-P. Birat Renewables-based decarbonization and relocation of iron and steel making: A case study, J. Ind. Ecol., 1-13 (2020), https://doi.org/10.1111/ jiec. 12997

101. POSCO to carry out Green Hydrogen project with Fortescu Metal Group, 4/01/2021, https://fuelcellsworks.com/news/ posco-to-carry-out-green-hydrogen-project-with-fortescuemetal-group/

102. Kawasaki Heavy aims to duplicate LNG supply chain with hydrogen, Reuters, 26/01/2021, https://www. reuters.com/article/us-japan-hydrogen-kawasakiheavy-idUSKBN29V0SW

103. J.-P. Birat, The greening of steel: The blast furnace in the garden, in: International Steelmaking Meeting, Charlotte, Congress Dinner Keynote Lecture, 9-12 May, 2005

104. J.-P. Birat, How to tell the story of change and transition of the energy, ecological and societal systems, Matériaux \& Techniques 108, 502 (2020), https://doi.org/10.1051/ mattech/2021005

Cite this article as: Jean-Pierre Birat, Fabrice Patisson, Olivier Mirgaux, Hydrogen steelmaking, part 2: competition with other Net-Zero steelmaking solutions-geopolitical issues, Matériaux \& Techniques 109, 307 (2021) 